\title{
Toward an Improved Understanding of the Marine Barium Cycle and the Application of Marine Barite as a Paleoproductivity Proxy
}

\author{
Samantha C. Carter ${ }^{1, *}$, Adina Paytan ${ }^{2}\left(\right.$ ) and Elizabeth M. Griffith ${ }^{1}$ (1) \\ 1 School of Earth Sciences, The Ohio State University, 125 South Oval Mall, Columbus, OH 43210, USA; \\ griffith.906@osu.edu \\ 2 Institute of Marine Sciences, University of California Santa Cruz, 1156 High Street, \\ Santa Cruz, CA 95064, USA; apaytan@ucsc.edu \\ * Correspondence: carter.1563@osu.edu; Tel.: +1-512-577-3501
}

Received: 24 April 2020; Accepted: 5 May 2020; Published: 9 May 2020

\begin{abstract}
Marine barite $\left(\mathrm{BaSO}_{4}\right)$ is a relatively ubiquitous, though minor, component of ocean sediments. Modern studies of the accumulation of barite in ocean sediments have demonstrated a robust correlation between barite accumulation rates and carbon export to the deep ocean. This correlation has been used to develop quantitative relationships between barite accumulation rates and export production and is used to reconstruct export production in the geologic past, particularly during times of dynamic changes in the carbon cycle. We review the processes that affect the formation and preservation of marine barite, as well as those controlling the relationship between the barium (Ba) and carbon biogeochemical cycles. Additionally, we take a new approach to modeling the marine Ba cycle as a two-box model, specifically evaluating Ba utilization in the surface ocean and refining the equation describing the relationship between export production and barite formation. We compare these new results with past modeling efforts. The new model demonstrates that increases in export production can lead to sustained increases in barite accumulation in marine sediments without resulting in complete surface water Ba depletion, which is distinctly different from previous modeling results.
\end{abstract}

Keywords: barite; $\mathrm{BaSO}_{4}$; export production; barium; carbon cycle

\section{Introduction}

The carbon $(\mathrm{C})$ cycle plays a critical role in global climate both in today's environment and in the geologic past (e.g., [1]). Export production-the flux of organic $\mathrm{C}\left(\mathrm{C}_{\mathrm{org}}\right)$ to the deep-ocean-plays a major role in the $\mathrm{C}$ cycle, as it removes $\mathrm{C}$ from the atmosphere and sequesters it in the deep-ocean for seasons to centuries (e.g., [2-4]). Increased productivity and/or changes in ecosystem structure in the surface waters can lead to higher export production and $C$ sequestration (e.g., [5]). Changes in the magnitude of export production in-turn can strongly influence atmospheric $p \mathrm{CO}_{2}$ levels (and hence climate) on geological time scales [3,6]. However, export production is difficult to quantify in the present day, and even more so in the geologic past.

Several methods have been employed to reconstruct export production, including accumulation of organic matter in marine sediments, benthic foraminiferal assemblages and accumulation rates, and more (e.g., [7]). However, each proxy has its own strengths, weaknesses, and inherent assumptions required to relate changes in the proxy measurement with export production. The accumulation rate of microcrystals of the mineral barite $\left(\mathrm{BaSO}_{4}\right.$; Figure 1$)$ in marine sediments has been widely used as a proxy for export production and will be reviewed here along with the role barite plays in the 
global marine barium (Ba) cycle. The goal of this paper is to shed light on the processes that affect the formation and preservation of marine barite in the modern ocean, as well as those controlling the coupling between the $\mathrm{Ba}$ and $\mathrm{C}$ biogeochemical cycles. We document recent progress achieved and identify gaps in our knowledge of the marine Ba cycle, review and suggest revisions to an existing two-box model of the marine Ba cycle, and recommend future studies that could enhance our ability to accurately interpret the marine barite sedimentary record in terms of past export production.
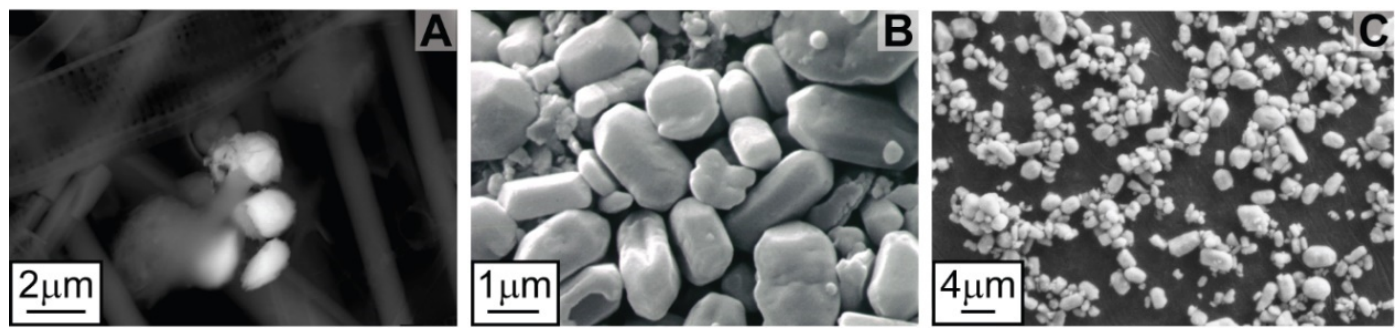

Figure 1. Images of marine barite $\left(\mathrm{BaSO}_{4}\right)$ using scanning electron microscopy. (A) Barite (bright white) in size-fractionated particulate matter collected from the water column in the North Atlantic. (B) Barite separated from sediments collected at the sediment-water interface in the Equatorial Pacific. (C) Barite separated from a middle Miocene ( 13.9 Ma) core sample from International Ocean Discovery Program (IODP) Site U1337 in the eastern equatorial Pacific, located $\sim 315 \mathrm{~m}$ below the seafloor.

\section{Barium Cycling: Processes in the Modern Ocean}

The global marine Ba cycle is controlled by input from land and from hydrothermal vents and by the removal of $\mathrm{Ba}$ from seawater as it accumulates in marine sediments primarily in the form of the mineral barite and in association with iron and manganese oxyhydroxides (Figure 2) [8-12]. Barium is associated with many rocks [13], which are weathered on the continents resulting in rivers and groundwater adding relatively large quantities of dissolved Ba to the surface ocean. Barium concentrations in the open ocean normally vary between values as low as $30 \mathrm{nmol} / \mathrm{kg}$ in surface waters and up to $150 \mathrm{nmol} / \mathrm{kg}$ in the deep Pacific [14-23]. Additional dissolved Ba can be introduced to deep waters through submarine hydrothermal systems [24,25] and cold seeps [26].

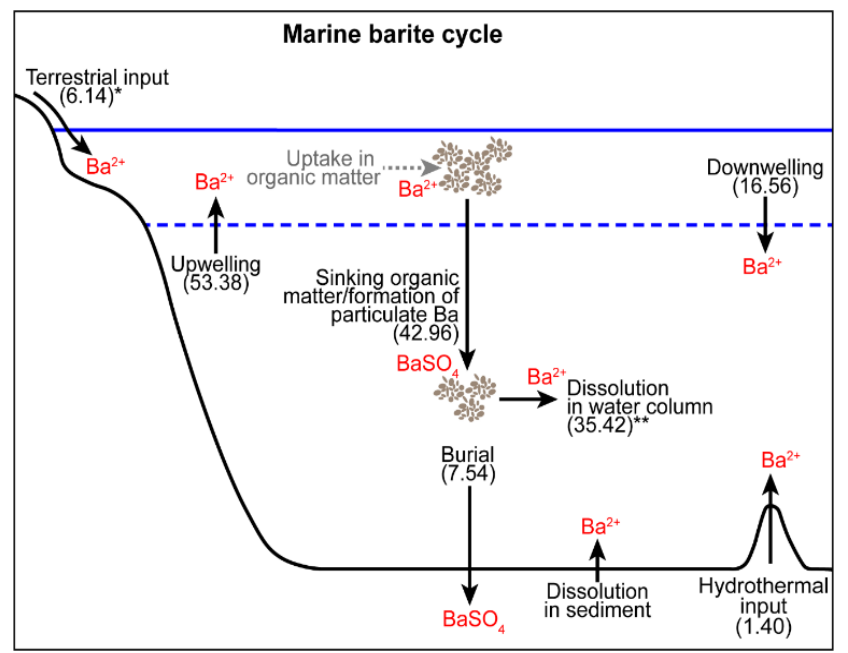

Figure 2. A simplified diagram of the marine barite cycle. Direction of fluxes are shown with black arrows, with the value of the flux in parentheses (in $\mathrm{nmol} \mathrm{cm}^{-2} \mathrm{yr}^{-1}$ ) [27]. The associated phase of barium (Ba) is shown in red, with $\mathrm{Ba}^{2+}$ as the dissolved phase and $\mathrm{BaSO}_{4}$ (barite) as the particulate phase. *-Terrestrial input includes river and groundwater discharge. ${ }^{*}$-Dissolution in sediment is included in the flux for dissolution in the water column. Note that Ba is also associated with other terrigenous and authigenic minerals not depicted in this figure (see discussion). 
Within the world's oceans, Ba has a nutrient-like distribution (Figure 3). Barium is removed from the water column during processes associated with organic matter production in the sunlit surface ocean (euphotic zone) and a fraction of this Ba is released at depth as sinking organic matter is remineralized. The process of remineralization refers to microbial respiration processes that convert organic matter into dissolved inorganic matter. Although most areas of the ocean are under-saturated with respect to the mineral barite, it is found ubiquitously in the water column, particularly in association with sinking organic matter and biogenic debris [12,28,29]. It is thought that marine barite precipitates extracellularly from seawater within microenvironments and aggregates where bacteria mediate organic matter degradation, primarily below the euphotic zone [12,21,22,28,30-34]. Sinking organic matter enriched in $\mathrm{Ba}$ [35] releases dissolved Ba upon remineralization and enables the establishment of supersaturated conditions within these microenvironments, promoting barite precipitation [12,29,36-38] (see further discussed in Section 2.2). However, because the ocean is largely under-saturated with respect to barite, a large fraction of the particulate barite $(\sim 70 \%)$ that forms in the water column dissolves at depth and within the upper few centimeters of the sediment [9,39-43]. Thus only a portion of precipitated barite accumulates in sediment and this fraction varies spatially ranging from $0 \%$ and up to $30 \%$, depending on sediment accumulation rates $[11,44]$. As a consequence of this overall cycling, dissolved Ba concentrations in deep water greatly exceed those in surface water and concentration maxima are observed in the subsurface at the depth of maximum organic matter remineralization [19-23,45]. Advection of water due to thermohaline circulation returns dissolved Ba from deep water to surface water, which also receives Ba input from rivers and groundwater discharge [20,46-50].

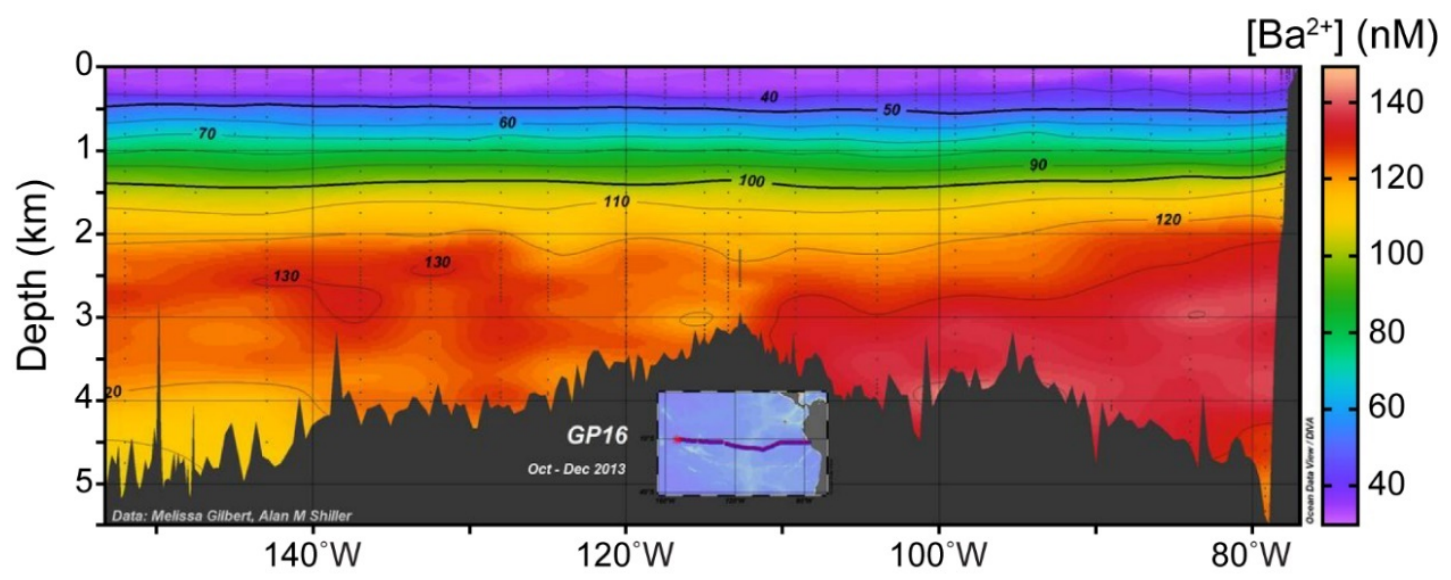

Figure 3. The distribution of dissolved barium $\left(\mathrm{Ba}^{2+}\right)$ along a transect in the eastern tropical Pacific Ocean (along latitude of $10^{\circ}-15^{\circ} \mathrm{S}$ ). The data were collected as part of GEOTRACES cruise GP16 [51] (figure produced using egeotraces.org [52]).

Although the residence time of dissolved Ba in open sea water is roughly four times that of the ocean mixing time (approximately 8 kyr; [53]), processes occurring within the ocean (barite formation and dissolution, advection) result in observable and predictable patterns in dissolved and particulate $\mathrm{Ba}$ and $\mathrm{Ba}$ isotopes (see below) which can be used to inform global Ba models and the Ba-C coupling (e.g., $[8,9,22,40,54])$. It is critical, however, to consider in more detail the processes controlling each flux within the marine Ba cycle in order to best model the system and understand how perturbations impact the marine Ba cycle and the sedimentary record of barite accumulation.

\subsection{Sources of Dissolved Barium to the Ocean}

The largest source of Ba to the ocean comes from terrestrial inputs, which includes rivers, with an average estimated global flux ranging from 2 to $6.14 \mathrm{nmol} \mathrm{cm}^{-2} \mathrm{yr}^{-1}$ [24,27,55-57], and groundwater, which has most recently been estimated to be $0.46 \mathrm{nmol} \mathrm{cm}^{-2} \mathrm{yr}^{-1}$ or $<25 \%$ of the river flux [58]. 
This Ba is sourced from rock weathering and desorption of Ba at intermediate salinities in riverine and subterranean estuaries $[50,58,59]$. Barium input into the ocean varies spatially, as the dissolved concentration of $\mathrm{Ba}$ in rivers varies considerably and similar geospatial variations exist in submarine groundwater inputs. In the Mediterranean, submarine groundwater discharge has recently been argued to significantly contribute to the Ba budget of the Mediterreanean, however large uncertainties still exist due to the high variability in groundwater chemistry [60]. Measurements of Ba concentrations from eight rivers around the world showed values as low as $47.8 \mathrm{nmol} \mathrm{kg}^{-1}$ in the Sepik River in Papua New Guinea, and as high as $1466.6 \mathrm{nmol} \mathrm{kg}{ }^{-1}$ in the Yukon River in northwestern North America [47]. Riverine or groundwater inputs may, however, locally increase Ba concentrations in coastal systems and estuaries (e.g., [48]). Indeed, dissolved Ba concentrations in coastal systems range between 50 and $200 \mathrm{nmol} \mathrm{kg}^{-1}$, higher than Ba concentrations in the surface waters of the open ocean (30-50 $\left.\mathrm{nmol} \mathrm{kg}^{-1}\right)$ [46,47,61-68].

The overall contribution of Ba sourced from hydrothermal systems and cold seeps to the global Ba cycle is not well quantified. Fluids sourced from these systems have high Ba concentrations, with hydrothermal fluids ranging from 10 to $40 \mu \mathrm{mol} \mathrm{kg}^{-1}$ [55] and similarly high concentrations have been reported at cold seeps $[26,69,70]$. Hydrothermal vents are estimated to contribute between $2 \%$ and $13 \%$ of the total Ba input to the ocean [24,55,61], with an estimated flux of 1 to $1.39 \mathrm{nmol} \mathrm{cm}^{-2} \mathrm{yr}^{-1}[9,27]$. However, barite mounds and chimneys locally precipitate in association with both hydrothermal and cold seep systems [70-72]. The precipitation of these barite mounds and chimneys can consume most, if not all, of the dissolved Ba, resulting in little to no net Ba flux to ocean water. The estimated flux given here, which has been previousely used in box models of the marine Ba cycle, does not consider how much $\mathrm{Ba}$ is consumed due to local barite precipitation, and thus is likely an overestimation. Future studies of hydrothermal (and cold seep) systems and their potential contribution to the ocean Ba budget could greatly benefit from the incorporation of Ba-isotopes [20] and estimates of the local solid phase sink in order to establish mass balance of Ba inputs and consumption due to local precipition.

\subsection{Barium Uptake and Release from Biogenic Material}

It has been well documented that barite precipitates in undersaturated seawater in association with sinking organic matter $[11,12,28,29,32,36-38,54]$. However, the processes that lead to precipitation of barite in these microenvironments are still poorly constrained, though significant progress has been made recently. Although Ba is not a primary nutrient (such as phosphate), plankton uptake dissolved $\mathrm{Ba}$, and the $\mathrm{Ba}$ content of marine phytoplankton grown in culture or in sinking organic matter is considerably higher than that of seawater [35,73]. However, dissolved Ba is never depleted in surface waters to the same extent as primary nutrients [20,22]. In a time-series decay experiment from laboratory and coastal plankton, the plankton which contained a large amount of labile Ba, released this Ba to the water upon decay (remineralization of the organic matter) [29]. The labile Ba pool in plankton could be within the cytoplasm of the living organisms, or adsorbed onto cells or extracellular organic matter [29,73]. Martinez-Ruiz et al. [31] show that marine bacteria facilitate the bioaccumulation of $\mathrm{Ba}$-specifically through binding with phosphate groups on organic biofilms (and other organic substrates), increasing Ba concentrations locally and forming nucleation sites for barite precipitation within these microenvironments.

\subsection{Barite Formation in the Water Column}

The process of barite precipitation is thought to occur mainly in the twilight zone ( 200-1000 m) where most organic matter is remineralized $[12,28,39,74]$. This is supported by the depth distribution of particulate barite in the water column $[28,75]$ as well as depth profiles of dissolved Ba and Ba isotopes which indicate barite formation at approximately 200-600 m depth [19,21,22]. Observations show that the highest particulate barite concentration in the water column in most regions of the ocean is associated with the oxygen minimum zone, where most organic carbon $\left(\mathrm{C}_{\mathrm{org}}\right)$ degradation occurs, providing further proof of the relationship between barite formation in the water column and organic 
matter degradation $[28,75,76]$. This distribution is also consistent with the role of bacteria in barite formation as bacterial activity consumes oxygen in the process of $\mathrm{C}_{\text {org }}$ respiration $[31,34,77,78]$. Indeed, in the ocean, a potential relationship between barite formation and microbial activity was identified from studies that showed higher mesopelagic particulate Ba was correlated with greater bacterial production $[34,77,78]$. Certain marine bacteria have been shown to mediate barite precipitation under experimental conditions [79-81]. Experiments with marine bacteria show that there are several common marine strains that have the capability to precipitate barite under laboratory conditions [79]. Results from laboratory and field studies suggest that bacteria, and particularly bacterial biofilms, play an important role in creating local elevations in Ba concentration that can subsequently interact with ambient sulfate to promote barite nucleation.

Martinez-Ruiz et al. [31] show that under experimental conditions common marine bacterial biofilms, or more specifically bacterial extracellular polymeric substances (EPS), concentrate Ba and establish nucleation sites in microenvironments where barite precipitates [31]. At the initial stages of Ba bioaccumulation, an amorphous phosphorus-rich phase is formed, which evolves into barite through substitution of phosphate with sulfate [31]. Because EPS is not associated with any specific organism, but is produced by a large range of microorganisms including phytoplankton and bacteria, barite formation via nucleation in EPS can occur throughout the ocean and is not linked to specific organisms [31]. A recent investigation of particulate material from the North Atlantic and Southern Ocean (upper $1000 \mathrm{~m}$ ) demonstrated that indeed barite formation in the ocean occurs within aggregates containing EPS-like material [32]. Phosphorous-rich, mostly amorphous or poorly crystallized phases were identified, suggesting a similar formation mechanism as observed in the controlled experiments. These results are consistent with a close link between bacterial degradation of organic material and abundance of Ba-rich particulates in the water column. Altogether the data suggests that bacteria and EPS play a major role in mediating marine barite formation in an undersaturated water column.

There are also a few other marine organisms that could potentially mediate barite formation. Acantharia are zooplankton whose shells are made of celestine $\left(\mathrm{SrSO}_{4}\right)$, which contains $\mathrm{Ba}$ at high concentrations and thus are suggested to promote barite supersaturation upon dissolution $[37,38,82]$. However, Ganeshram et al. [29] show that barite can form in mesocosm decay experiments in the absence of acantharia, indicating that these organisms are not necessary for the barite precipitation process. A direct biotic mechanism of barite precipitation intracellularly occurs within some algae, where these barite crystals act as statoliths to maintain orientation and depth, and possibly within certain protozoa such as benthic xenophyophores, although it is unclear if they actively precipitate barite or selectively retain it during filter feeding [83-86]. However, there is no clear correlation between the abundance of these organisms and barite concentration in the water column or in marine sediment, indicating that biotic precipitation within living organisms in the marine water column is not the primary mechanism for barite formation [33]. Although there is no quantitative estimate for the contribution of direct barite precipitation within living organisms to the total barite budget, it is most likely insignificant [87].

\subsection{Barite Dissolution in Deep Water}

The flux of barite to marine sediments depends not only on barite formation, but also on the degree of barite dissolution in the water column. Barite preservation in the water column in-turn depends on barite saturation state in intermediate and deep waters, which is controlled by the concentration of dissolved $\mathrm{Ba}$ as well as pressure and temperature [45]. The degree to which barite is dissolved in the water column is not well constrained in most areas of the ocean. Dissolution rates of barite are high in marine anoxic basins where the water column is sulfate reducing, such as the Black Sea, resulting in concentrations of $\mathrm{Ba}$ as high as $460 \mathrm{nmol} \mathrm{kg}{ }^{-1}$ [88]. In these permanently anoxic basins, maximum concentrations of dissolved $\mathrm{Ba}$ in the water column occur near the redox interface, whereby microbial activity promotes the breakdown of settling particulate matter and the release of $\mathrm{Ba}$ from the dissolution of barite [88]. Ba associated with other phases such as $\mathrm{Mn} / \mathrm{Fe}$ oxides may also be released in suboxic 
or anoxic environments. It is therefore important to consider the chemistry of water masses when establishing a relationship between export production and barite accumulation. Specifically, variability in barite accumulation in the past could be attributed to changes in dissolution and preservation in the water column and in the sediments (see below), not just export productivity.

It has been suggested through modeling and pore-water flux measurements that most barite dissolution occurs within the first few centimeters of the sediment, as much as 85\% [9] (see section below). The degree of barite dissolution in the water column is not well quantified, and our understanding of this process would benefit from future works investigating how the aggregates of organic matter affect the exposure of precipitated barite to undersaturated water. It follows that barite dissolution in the water column would occur at a faster rate if the waters were more undersaturated. However, if the barite particles are contained in aggregates, this may prevent exposure to undersaturated waters, increase sinking rates and thus reduce dissolution rates in the water column [87]. At what point disaggregation in the water column results in the exposure of the precipitated barite to undersaturated conditions is an interesting direction for future research. Additionally, not all of the Ba is contained within organic matter precipitates as barite [29], thus upon degradation dissolved Ba will be released to surrounding water without necessitating the dissolution of barite or any dependency on barite saturation state (and thus deep water Ba concentrations). How much Ba is consumed in the precipitation of barite as organic matter degrades and how much remains as dissolved Ba is another open question, but initial work suggests it is a small fraction [29].

\subsection{Barite Preservation in Sediments}

The preservation of barite in sediments is strongly dependent on the environment of deposition. As marine barite accumulates on the seafloor, a fraction dissolves on and in the upper few centimeters of sediments $[9,41]$. Most labile Ba (i.e., the fraction not associated with aluminosilicates) exists as barite and Fe-Mn oxyhydroxides in sediments, and only a small amount of the total Ba in the sedimentary column is present as dissolved Ba in porewater [41,89]. A study analyzing pore waters from seven sites across an equatorial Pacific transect showed that approximately $30 \%$ of the particulate Ba flux to the deep ocean in the equatorial Pacific is preserved in the sediments at this site [9]. This is likely not the case in areas with lower barite accumulation rates and lower sedimentation rates where the exposure time of barite to undersaturated seawater is much longer. We expect that barite preservation would be much lower in those regions. Paytan and Kastner [9] also estimated how much dissolution of barite in the sediment contributed to the total dissolution of sinking particulate barite, suggesting that most of the dissolution occurs within the sediment $(\sim 85 \%)$, thus very little dissolution occurs in the water column. As the barite is dissolved, Ba concentrations in the upper few centimeters of the sediments are higher than those of bottom water, leading to a diffusive flux of Ba from the sediments into the deep ocean [9]. Indeed, examining water column depth profiles of the isotopic composition of dissolved $\mathrm{Ba}$ indicates that there is a non-conservative component (i.e., additional input of $\mathrm{Ba}$ ) to the overall conservative mixing behavior of the oceanic deep-water masses. This non-conservative behavior could indicate the addition of Ba to deep water by dissolution of barite in the sediment, from Ba released from sinking particles in the water column, or from hydrothermal input [20].

The solubility of barite increases drastically when pore waters become depleted in sulfate resulting in dissolution of sedimentary barite and an associated increase in the concentration of dissolved $\mathrm{Ba}$ in porewaters by up to four orders of magnitude [26,90-92]. Dissolution occurs at and below the sulfate methane transition (SMT) zone where microbial methanogensis occurs. In certain areas, such as those with high rates of sedimentation and production, sulfate is rapidly depleted with depth in the sediment as a result of microbial sulfate reduction [92]. In these areas, below the SMT zone where sulfate is completely depleted, barite slowly dissolves, Ba is released and diffuses upward in the sediment column, back into regions with sulfate-rich porewater, causing it to re-precipitate as diagenetic barite [26,71,91-95]. Where the diffusion rate is fast the diagenetic front is close to the surface, or where there is also advection of porewaters (such as at cold seeps, for example), 
the dissolved Ba may be released at the sediment-water interface and precipitate there as barite mounds and concretions $[26,69,71]$. This diagenetic barite is morphologically different than marine barite [96] and can typically be easily identified using electron microscopy and isotopic analyses [97,98].

\subsection{New Insights from Barium Isotopes}

Relatively recent studies have investigated the distribution and fractionation of stable Ba isotopes in seawater and marine sediments in an effort to elucidate processes involved in the marine Ba cycle [19-23,47]. Ba isotopic composition is reported in delta notation relative to a standard. Some works report ratios of ${ }^{138} \mathrm{Ba}$ to ${ }^{134} \mathrm{Ba}$, while others report ${ }^{137} \mathrm{Ba}$ to ${ }^{134} \mathrm{Ba}$. Any $\mathrm{Ba}$ isotopic values reported here are ratios of ${ }^{138} \mathrm{Ba}$ to ${ }^{134} \mathrm{Ba}$ relative to the National Institute of Standards and Technology (NIST) Ba Standard Reference Material (SRM) 3104a ( $\left.\delta^{138} \mathrm{Ba}\right)$ such that:

$$
\delta^{138} \mathrm{Ba}=\left(\frac{{ }^{138} \mathrm{Ba} /{ }^{134} \mathrm{Ba}_{\text {sample }}}{{ }^{138} \mathrm{Ba} /{ }^{134} \mathrm{Ba}_{\text {NIST SRM 3104a }}}-1\right) \times 1000
$$

The precipitation of barite preferentially incorporates the lighter isotopes of Ba [19-22,99], leaving residual waters isotopically 'heavier' with higher values of $\delta^{138} \mathrm{Ba}$. Depth profiles from multiple ocean basins, including the Atlantic [19-23], North Pacific [20], Southern Ocean [20,23], and South China Sea and East China Sea [47] show the Ba isotopic composition of seawater ranges from +0.24 to $+0.65 \%$, with a general decrease with depth. Seawater Ba isotopic composition is relatively constant in surface waters (above $200 \mathrm{~m}$ ) [19,20,22,47], which suggests that the process that removes $\mathrm{Ba}$ from the surface is slow in relation to supply and mixing [20]. There is an increase in $\delta^{138} \mathrm{Ba}$ between 200 and $600 \mathrm{~m}$, suggesting that most barite precipitation occurs between these depths [21,22]. In the deep ocean, Ba isotopes are strongly influenced by regional circulation. Variations in isotopic composition reflect mostly conservative mixing of water masses [21,22,47]. Overall, there is a strong global correlation between dissolved $\mathrm{Ba}$ and $\delta^{138} \mathrm{Ba}$, which indicates that the processes controlling $\mathrm{Ba}$ are consistent in all ocean basins [19-23,47].

There are some regional differences in this overall profile. Surface water Ba isotopes are not as homogenous in areas of upwelling or near large river inputs [20,21]. Rivers have relatively high Ba concentrations and are isotopically light compared to seawater values (low $\delta^{138} \mathrm{Ba}$ values), so that surface waters near large river input are light (low $\delta^{138} \mathrm{Ba}$ values). However, the overall trend in $\delta^{138} \mathrm{Ba}$ with depth in these areas still shows the influence of barite precipitation in shallower water, and water mass mixing in deep water [20,47]. Additionally, in the tropical North Atlantic, Ba isotopic variations near the sediment show the opposite trend of what would be expected if there is a diffusive flux of Ba derived from the dissolution of barite in the sediment, that is, $\delta^{138} \mathrm{Ba}$ near the sediment is slightly heavier than the $\delta^{138} \mathrm{Ba}$ in the above water column, suggesting that there is only a slight overprint of dissolved Ba diffusing from the sediment that originates from barite on the overall control by ocean circulation [21]. Other areas in the deep ocean also deviate slightly from conservative-mixing behavior that indicate there is a component that is non-conservative [20]. This non-conservative behavior is likely due to an additional source of Ba to deep water, such as Ba released from settling particles, flux from sediments, or hydrothermal fluids [20].

Additionally, the utilization of Ba in surface waters (i.e., how much Ba is removed from the surface relative to how much is upwelled) varies within different ocean basins. Using $\delta^{138} \mathrm{Ba}$ and $\mathrm{Ba}$ concentrations in different ocean basins, Hsieh and Henderson [20] estimate that utilization is higher in the North Pacific, followed by the South and North Atlantic, and lowest in the Southern Ocean. The higher utilization rates are suggested to be caused mainly by slower upward mixing of water masses [20].

A coupled sediment-water column study of Ba isotopes along a transect from the Uruguayan continental margin to the Mid Atlantic Ridge showed a predictable pattern of mixing of sediments between two sources, one a detrital source from the continents and the other from marine barite [19]. 
These two sources do not have distinctly different Ba isotopic compositions [19], thus methods will need to be applied (such as aluminum content) in order to rule out the influence of continental material if using $\mathrm{Ba}$ isotopes of marine sediments to investigate changes in export production [19]. Overall, the strong global correlation between dissolved $\mathrm{Ba}$ and $\delta^{138} \mathrm{Ba}$ suggests that isotopic fractionation related to marine barite precipitation is relatively constant throughout the ocean [19-23,47] and it is hypothesized that the $\delta^{138} \mathrm{Ba}$ of sediments in the open ocean could reflect variations in input to and removal of dissolved $\mathrm{Ba}$ (by marine barite precipitation) from the upper ocean, which could help to constrain export production in the geologic past [19].

\section{Marine Barite Accumulation in the Present and Past and the Global C Cycle}

Barite accumulation rates (BAR) in core top sediments have been shown to have a strong correlation with $\mathrm{C}_{\text {org }}$ export from the euphotic zone, or 'export production' $[44,100]$. Assuming the processes which govern barite precipitation and accumulation in deep sea sediments have remained constant through time, changes in BAR reflect variations in export production and can be used to reconstruct changes in export production in the geologic past [11,42,44,100-110]. Indeed, barite accumulation in marine sediments has been used as a proxy for export production, which in turn depends on primary production (among other things). Differences in the efficiency of $C$ export from the euphotic zone impacts BAR and the relationship between BAR and primary production [100]. When combined with proxies for primary production, changes in the efficiency of $C$ export (and the biological pump) can be investigated for past geological times (e.g., $[107,108])$ providing insight into feedbacks and controls on the global C cycle.

\subsection{Relationship between Excess Barium Flux and C Export in the Water Column}

Organic C $\left(\mathrm{C}_{\text {org }}\right)$ and excess $\mathrm{Ba}\left(\mathrm{Ba}_{\mathrm{ex}}\right)$ flux data (total $\mathrm{Ba}$ corrected for terrigenous $\mathrm{Ba}$ using $\mathrm{Al}$ normalization) measured from sediment traps have been used in a variety of oceanic regions in order to develop algorithms that link $\mathrm{Ba}_{\mathrm{ex}}$ rain rate (presumed to be primarily in the form of barite) to export production [11,40,54,111-116]. While many studies of sinking particles in sediment traps have shown a robust correlation between fluxes of $\mathrm{C}_{\text {org }}$ and $\mathrm{Ba}_{\mathrm{ex}}$ in the water column (Figure 4), there are differences between trends at study sites located close to the continental margin and those located in the open ocean, and within different ocean basins [11,40,54,112,114-116].

The ratio of $\mathrm{C}_{\text {org }}: \mathrm{Ba}_{\mathrm{ex}}$ has been shown to decrease with depth, a trend that is well established in many oceanographic settings (Figure $4 \mathrm{~A}$ ) [11,40,54,112,114-116]. The decrease of $\mathrm{C}_{\text {org }} / \mathrm{Ba}_{\mathrm{ex}}$ occurs due to the remineralization of $\mathrm{C}_{\text {org }}$, which occurs at an exponentially decreasing rate with depth (e.g., [117]), but is also impacted by precipitation of barite that occurs between 200 and $600 \mathrm{~m}$ depth [21,22]. The relationship between the ratio of $\mathrm{C}_{\text {org }}$ to $\mathrm{Ba}_{\mathrm{ex}}$ with water depth has been described using two equations:

$$
\begin{aligned}
& \frac{\mathrm{C}_{\text {org }}}{\mathrm{Ba}_{\mathrm{ex}}}=73770 \times \mathrm{z}^{-0.85} \\
& \frac{\mathrm{C}_{\text {org }}}{\mathrm{Ba}_{\mathrm{ex}}}=4787 \times \mathrm{z}^{-0.616}
\end{aligned}
$$

where $\mathrm{z}$ is water depth $(\mathrm{m})$. Equation (2) has been found to be more descriptive of sites located in margin systems [111], while Equation (3) better describes the relationship seen in open ocean settings [40].

The ratio between $\mathrm{C}_{\text {org }}$ and $\mathrm{Ba}_{\mathrm{ex}}$ also shows differences between margin and open ocean settings that are unrelated to depth (Figure 4A,B). These differences are attributed to processes that affect the sinking rate of organic matter [116]. Processes that affect organic matter sinking rate could be differences in community structure, such as the composition of phytoplankton and grazer communities, that control the formation of aggregates and thus the sinking rate [54,111,118,119]. Additionally, kinetics may play a role, as higher rates of productivity will lead to an increase in the sinking rate of the organic matter due to the formation of aggregates, causing less time for decomposition and barite 
formation in the water column [87]. Spatial variations in the $\mathrm{C}_{\mathrm{org}}: \mathrm{Ba}_{\mathrm{ex}}$ ratio could also be caused by (1) input of terrestrial $C$ which is more resistant to regeneration [40], though some studies have ruled this as negligible, particularly in open ocean settings, (2) Ba associated with a non-barite phase that is not accounted for (such as iron oxyhydroxides; [73]), or (3) the spatial variability of barite saturation state [45], leading to site specific barite dissolution rates that affect the ratio in sediment traps.
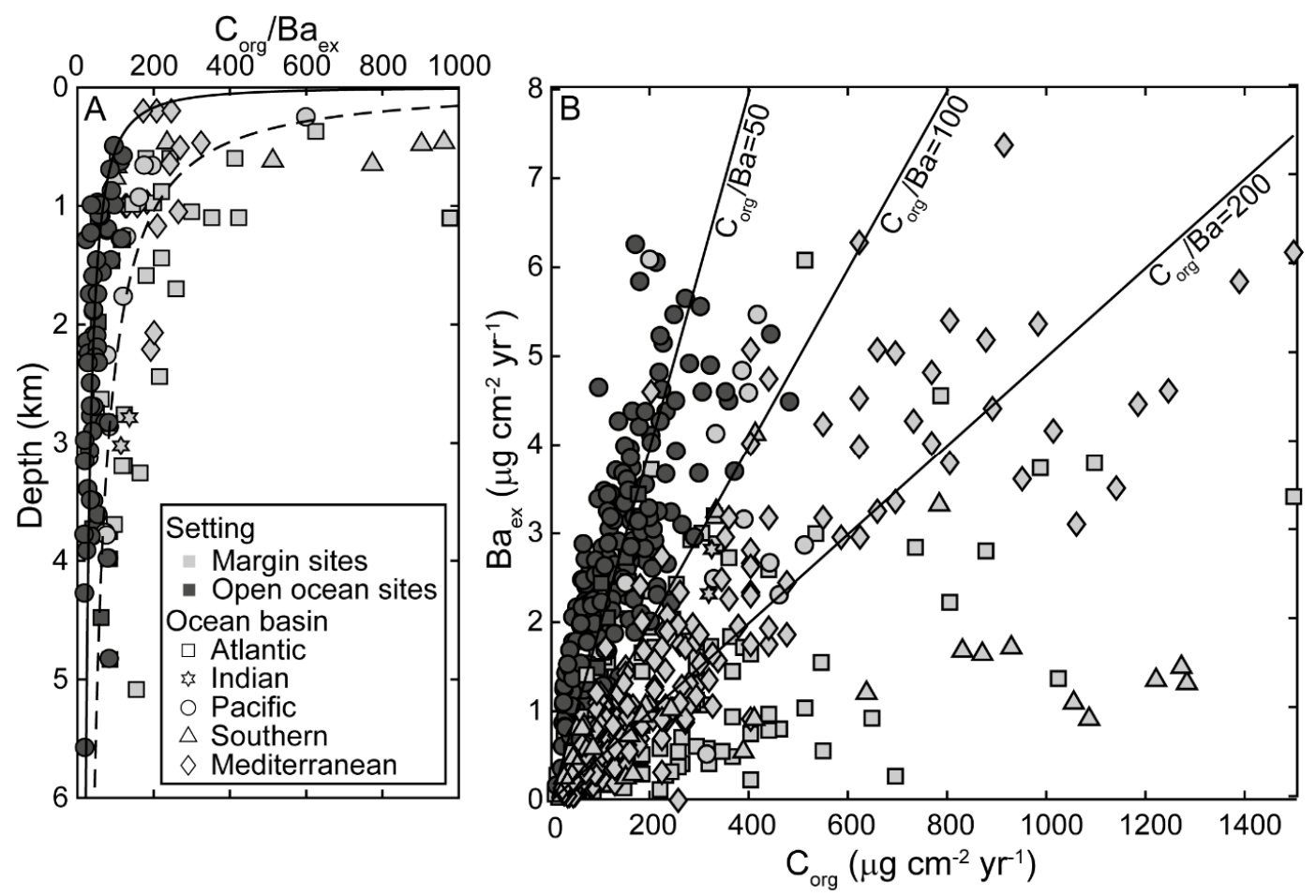

Figure 4. Sediment trap data from margin sites (light gray) and open ocean sites (dark gray). (A) Site averages of organic carbon:excess $\mathrm{Ba}\left(\mathrm{C}_{\mathrm{org}} / \mathrm{Ba}_{\mathrm{ex}}\right)$ ratio versus depth, with different equations describing the relationship shown (solid-[40]; dashed-[111]). (B) Ba $\mathrm{ex}_{\mathrm{ex}}$ flux versus $\mathrm{C}_{\mathrm{org}}$ export. Different symbols denote different ocean basins, the Atlantic Ocean (squares) [11,40,111,116], the Indian Ocean (stars) [40], the Pacific Ocean (circles) [11,40,54], the Southern Ocean (triangles) [112,113], and the Mediterranean Sea (diamonds) [114,115].

Initially, it was thought that the water column particulate Ba flux to the seafloor is enhanced by higher Ba contents in deep and intermediate water, thus the relationship between $\mathrm{C}_{\text {org }}$ export and $\mathrm{Ba}_{\mathrm{ex}}$ flux was thought to be related to dissolved Ba concentrations at depth, which increases along the path of bottom water flow from the Atlantic to the Pacific [11]. However, the relationship does not hold in areas with very high rates of $C$ export such as the equatorial Pacific Ocean [54], where the flux of particulate Ba to the seafloor is less than would be expected. Other studies have found that a logarithmic relationship between fluxes of $\mathrm{C}_{\text {org }}$ and $\mathrm{Ba}_{\mathrm{ex}}$ better fit their data, which show a levelling off of the flux of $\mathrm{Ba}_{\mathrm{ex}}$ as $\mathrm{C}_{\text {org }}$ export increases $[40,120]$. However, this logarithmic behavior is not seen in all environments including the Mediterranean Sea which shows a more linear relationship even at enhanced levels of $\mathrm{C}_{\text {org }}$ flux [115].

It is clear from the data (and worth further investigation) that the relationship between export $\mathrm{C}$ and excess $\mathrm{Ba}$ in sinking biogenic debris is spatially heterogeneous. Sediment trap data of $\mathrm{C}_{\text {org }}$ and $\mathrm{Ba}_{\mathrm{ex}}$ fluxes discussed here highlights the fact that some areas exhibit a linear relationship between the two parameters, while others exhibit a logarithmic relationship (Figure 4) [11,40,54]. However, while sediment trap data is critical for understanding processes that are occurring in the water column, core top sediment data is more relevant for paleoceanographic reconstructions because it integrates all of the above processes at one location, and it is the marine sediment archive that is 
used for paleoceanographic reconstructions. In other words, assessing the relationship between $\mathrm{Ba}_{\mathrm{ex}}$ accumulation and $\mathrm{C}$ export in core top sediments is important for paleo applications, as the sediments are what can be measured back through time. Moreover, when using Ba as a productivity proxy it is important to consider the type of data used and its source. As described in the following section, a linear relationship is appropriate if using core- and seafloor sediment-derived data, while a logarithmic relationship may be more appropriate for most sediment trap data or when modeling processes in the water column.

\subsection{Barite Accumulation in the Modern Ocean}

Barite accumulation has been determined from core-top sediments at several locations in the modern ocean including the equatorial Pacific, Southern Ocean, Atlantic and Indian basins and has been used to derive export production [100]. When comparing to primary productivity estimates in a region, the relationship to BAR is site-specific, with different regression slopes apparent in different ocean basins. However, once primary production is converted to $\mathrm{C}$ export using an f-ratio appropriate for each region, the relationships of BAR and $C$ export from all ocean basins converge to a single global relationship [100] (Figure 5). The f-ratio is the fraction of total production accounted for by new production. It is notably a simple linear relationship that does not require measurements of seawater Ba concentrations, however, it is cautioned that one must consider the caveats associated with the proxy in order to make accurate predictions of paleoproductivity, as discussed below [100].

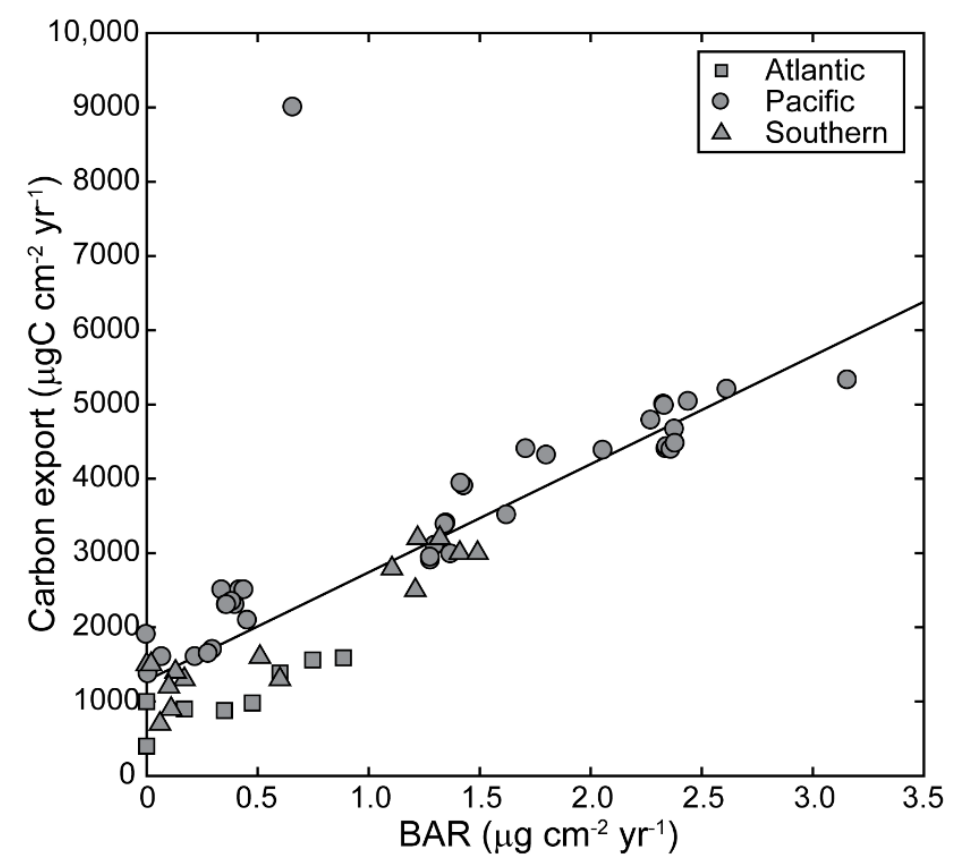

Figure 5. Barite accumulation rates (BAR) versus carbon export. Carbon export values are calculated by applying a region-specific f-ratio to primary productivity estimates. Symbols denote measurements from different ocean basins, the Atlantic Ocean (squares) [100], Pacific Ocean (circles) [44,100], and Southern Ocean (triangles) [100]. The line indicates the global regression for BAR and C export, with an $\mathrm{r}^{2}$ value of 0.81 [100]. The single outlier, from the Peru Margin, is likely affected by diagenesis, as these sediments are typically anoxic. If the Peru Margin point is not included in the global regression, the $\mathrm{r}^{2}$ value is 0.89 [100].

The equatorial Pacific is a narrow region characterized by high productivity induced by the upwelling of deep, nutrient-rich waters. This high productivity results in a high biogenic sedimentation rate, which has been present for at least throughout the Neogene [121,122]. Because of the high levels of primary productivity in this region, it contributes a significant percentage (18-56\%) of global new 
production [123], and thus plays a major role in the global C cycle. The significance of this region is reflected in BARs, which are highest in the equatorial Pacific compared to other ocean basins, with BAR over $30 \mu \mathrm{g} \mathrm{m}^{-2} \mathrm{yr}^{-1}$, corresponding to an export flux of $\sim 55 \mathrm{~g} \mathrm{C} \mathrm{m}^{-2} \mathrm{yr}^{-1}$ [100]. Notably, a distinct BAR gradient has been documented across the Equatorial Pacific zone with lower values to the north and south of the Equator, and also decreasing values from the Eastern to the Western Pacific as expected from the present-day productivity trends [44].

Compared to the equatorial Pacific, the Atlantic has much lower BAR values $\left(<10 \mu \mathrm{g} \mathrm{m}^{-2} \mathrm{yr}^{-1}\right)$ at similar levels of primary production [100]. However, when the appropriate f-ratio is applied to convert this primary production to $C$ export, the Atlantic value converge to the linear relationship that represents all ocean basins, though they tend to fall slightly below the global regression line [100]. This may be due to lower preservation of barite in the Atlantic, which has lower Ba concentrations and thus a lower saturation state [45], or the f-ratio used may overestimate the actual export production [100].

The Southern Ocean has much more efficient $C$ export, thus BAR is high relative to primary production [100]. The Southern Ocean samples fall reliably on the global BAR-C export regression line defined by measurements in core-top sediment, thus this relationship could more accurately be used in paleo reconstructions in this region [100].

Few studies have measured barite accumulation within the Indian Ocean in the modern day $[102,124]$. Measurements from box core samples taken from several sites in the northern Arabian Sea showed a pattern of barite formation that is not consistent with the pattern shown in other ocean basins [124]. The inconsistency was attributed to low barite preservation at the sediment-water interface. Alternatively, waters of the Arabian Sea tend to be oxygen-depleted at midwater depths, leading to sulfate reducing conditions, possibly inhibiting the growth of barite [124]. Furthermore, Francois et al. [40] also found that a large fraction of $C_{\text {org }}$ deposited in the deep Arabian Sea appeared to be refractory $C_{\text {org }}$ redistributed form the nearby shelves, which may not contribute to barite formation.

\subsection{Temporal Variability of Barite Accumulation and Implications for Carbon Export}

Records of $\mathrm{Ba}_{\mathrm{ex}}$ and $\mathrm{BAR}$ in sediments have been used to investigate variations in export production during time periods of dynamic climate variability in the geologic past. High resolution records show cyclic variations in BAR which corresponded to glacial-interglacial cycles, with maxima occurring during glacial periods (or deglacial transitions) and minima occurring during interglacials $[44,93,105]$. This has been attributed to stronger winds which intensify Ekman-induced upwelling in equatorial regions during glacials, fostering high productivity, or to changes in the nutrient content of the upwelling water due to changes in circulation. Similarly, it has been suggested that fluctuations of high productivity in the equatorial Pacific over the Neogene have also been consistently forced by Ekman-induced upwelling and circulation changes, which actually extends to the Eocene [122]. However, there are enigmatic transients superimposed on this overall pattern associated with nutrient supply reorganization, especially over the Miocene [107,125]. BAR records from the Paleogene suggest that export production was high at the onset of Antarctic glaciation and thus may have contributed to $\mathrm{C}$ sequestration and $p \mathrm{CO}_{2}$ drawdown prior to the Eocene-Oligocene transition [108]. BAR fluctuations appear to have power at both the $405 \mathrm{kyr}$ long eccentricity cycle as well as the 96-126 short eccentricity cycles indicating a strong coupling with orbitally forced climate changes [108].

There has been an ongoing debate regarding productivity changes over the Paleocene-Eocene Thermal Maximum (PETM) at $\sim 55.9$ Ma. The PETM is a relatively rapid event ( 170 kyr) [126] that marks a major perturbation of the global $C$ cycle, indicated by a global negative $C$ isotope excursion $[127,128]$. Records of $\mathrm{Ba}_{\mathrm{ex}}, \mathrm{BAR}$, and $\mathrm{Ba}$ isotopes show changes in export production over the time period $[101,106,129]$, which suggest increased export production helped reduce atmospheric $p \mathrm{CO}_{2}$ and rapidly return global temperatures to pre-PETM values, coined the "productivity feedback hypothesis" [101]. However, changes in BAR conflict with some other productivity proxies obtained from some of the same sites [130-133]. It has been argued that the destabilization of methane hydrates released large amounts of $\mathrm{Ba}$ into the ocean, thereby increasing barite preservation rates and impacting 
calculated BAR and export production reconstructions [27]. This suggestion is based primarily on a model of the oceanic Ba cycle (see discussion below).

\section{Modeling the Marine Ba Cycle and Implications for Barite as a Paleoproductivity Proxy}

\subsection{Existing Models and Their Findings}

The marine Ba cycle has been previously described using a two-box model with distribution of Ba in two major ocean reservoirs, surface and deep water, controlled by ocean circulation, vertical particulate Ba flux in the ocean, sources from rivers and hydrothermal vents, and the primary sink of particulate $\mathrm{Ba}$ (barite) accumulation in sedimentation $[8,9,27]$. The first modeling efforts for the marine Ba cycle in the ocean were performed by Wolgemuth and Broecker [8], which made assumptions regarding the riverine flux of $\mathrm{Ba}$, the rate of exchange between the surface and deep water reservoirs, and the $\mathrm{Ba}$ concentration of the upwelling and downwelling waters. With these assumptions, in order to balance the surface water reservoir, removal of Ba from the surface by organic matter was found to be $4.4 \mu \mathrm{g}$ $\mathrm{cm}^{-2} \mathrm{yr}^{-1}$. Therefore, in order to balance the deep-water reservoir, $0.6 \mu \mathrm{g} \mathrm{Ba} \mathrm{cm}{ }^{-2} \mathrm{yr}^{-1}$ must be lost to sediment and $3.8 \mu \mathrm{g} \mathrm{cm}^{-2} \mathrm{yr}^{-1}$ must dissolve, suggesting that $13.6 \%$ of the particulate barite flux is preserved in the sedimentary record, while the majority $(86.4 \%)$ is dissolved and enters the deep ocean dissolved Ba inventory.

Paytan and Kastner [9] assessed the influence of a benthic Ba flux from the sediment on the dissolved Ba content of deep waters in oxic sediments in the pelagic environment. First, benthic Ba fluxes from the sediment into the deep ocean were calculated using porewater Ba gradient measurements from an equatorial transect in the eastern Pacific. To assess whether these values were consistent with mass balance considerations, a two-box model was constructed. This model updated the input fluxes used by Wolgemuth and Broecker [8] with newer measurements of riverine input [56], added a hydrothermal input into the deep ocean [55], and adjusted the exchange between deep and surface water to correspond to a deep water residence time of $1100 \mathrm{yr}$. Additionally, in this model average concentrations of Ba in surface water of $36 \mathrm{nmol} \mathrm{kg}^{-1}$ and $116 \mathrm{nmol} \mathrm{kg}^{-1}$ in the deep water were used [16]. This model used similar values for upwelling/downwelling fluxes as Wolgemuth and Broecker [8] and only a slightly lower percentage for the amount of particulate Ba that is dissolved (82\%). Of that dissolved flux, the majority occurs within the sediment $(85.6 \%)$ with Ba fluxes from the sediment to the deep ocean much higher than what had been previously estimated. Measurements show that more productive regions, such as the equatorial divergence and coastal upwelling zones, contribute a higher flux of Ba from the sediment into the deep ocean compared to open ocean sediments [41]. Overall, Paytan and Kastner [9] suggested that approximately $70 \%$ of the barite arriving to the sediments is dissolved, while up to $30 \%$ is preserved.

Following these estimates Dickens et al. [27] created a numerical model using a system of equations for the marine Ba cycle and performed a series of sensitivity tests to evaluate how barite accumulation changes in response to increased productivity. The model was constructed to represent the modern ocean, with flux values representing modern estimations. This model introduced three new parameters that were not included in previous box models in order to couple Ba fluxes in numerical simulations. These parameters are $\mathrm{D}$, a coefficient linking Ba concentrations in surface water to the Ba content in organic matter, $\mathrm{f}$, which represents the fraction $(0-1)$ of the particulate Ba rain incorporated into the sediment, and $[\mathrm{Ba}]_{S a t}$, the dissolved Ba concentration at barite saturation used to calculate the value of $\mathrm{f}$. Using this numerical model, a sensitivity experiment was conducted by increasing primary productivity by $15 \%, 50 \%$, and $100 \%$. In these simulations, enhanced productivity increases the particulate rain of barite, however, the Ba reservoir in surface water drops precipitously, thereby reducing particulate rain (Figure 6). Thus, sustained increases in productivity resulted in a sharp peak in barite accumulation that quickly drops after the surface reservoir is depleted (bottom left panel of Figure 6). Dickens et al. [27] argue that long periods of increased barite accumulation are not sustainable and if observed in the sedimentary record they do not represent periods of export production, but rather periods of 
high barite preservation due to increased flux of dissolved Ba into the ocean, thereby increasing the concentration of $\mathrm{Ba}$ in the deep ocean leading to reduced dissolution. This mechanism was used to explain values of high barite accumulation over the PETM, which is argued to be caused by a large release of methane from marine sediments. Such methane release also contains large amounts of Ba associated with the SMT in the sediment and constitutes a potentially new source of dissolved Ba to the deep ocean. We note however that the expulsion of additional Ba from porewater is likely to result in local precipitation of barite at the sites of release as seen today in cold seeps, hence this flux might not contribute significant amounts of dissolved Ba to seawater [26,134,135].

\subsection{A Reevaluation of the Box Model}

Here, we make a few adjustments to the numerical model of Dickens et al. [27] to better represent what is known of the Ba cycle. The new model uses a system of flux equations (Table 1) and constants (Table 2) to describe the marine Ba cycle (Figure 2). The relationship between the particulate rain of Ba $\left(\mathrm{F}_{\mathrm{PR}}\right)$ and the downward flux of $\mathrm{C}_{\text {org }}\left(\mathrm{P}_{\mathrm{Org}}\right)$ is adjusted. The incorporation of Ba into organic matter and the subsequent formation of barite or particulate $\mathrm{Ba}$ and its flux to the seafloor is independent of surface Ba concentrations as suggested by [40]. We perform two sets of sensitivity experiments, the first using the following equation to relate $\mathrm{F}_{\mathrm{PR}}$ and $\mathrm{P}_{\mathrm{Org}}$ :

$$
\mathrm{F}_{\mathrm{PR}}=\mathrm{b} \times \mathrm{P}_{\mathrm{Org}}
$$

where $\mathrm{b}$ is a constant relating the growth of particulate $\mathrm{Ba}$ to $\mathrm{C}_{\text {org }}$ export. The value for $\mathrm{b}$ is set to 0.0137 , in order to maintain mass balance of Ba during steady state. The system of equations is solved in Matlab using an explicit Runge-Kutta 4,5 method. In the first set of sensitivity experiments, we use Equation (4) to describe $F_{P R}$. Three experiments are performed, the first increases $P_{\text {Org }}$ by 15\% (Figure 6; blue), the second increases $P_{\text {Org }}$ by 36\% (Figure 6; green) and the third increases two parameters, $P_{\text {Org }}$ by $100 \%$ and C (exchange of surface and deep waters; Table 2) by 65\%. In order to investigate how the system responds and recovers from each experiment, each perturbation is held constant for $1 \mathrm{kyr}$, then the experiment is returned to the original steady-state values.

Increasing the $\mathrm{P}_{\mathrm{Org}}$ flux has a similar impact on the shallow and deep-water concentrations of dissolved $\mathrm{Ba}$ as reported in Dickens et al. [27], that is the deep-water concentration increases, while the shallow water decreases (Figure 6). However, barite accumulation in sediments shows very different trends than what is seen in Dickens et al. [27]. There is an increase in barite accumulation that is maintained for the entire duration of the $C$ export increase. In our model, shallow water is more sensitive to depletion during times of enhanced $C$ export. In Dickens et al. [27], the fact that $F_{P R}$ depended on surface concentrations inherently meant less dissolved Ba would be converted into particulate $\mathrm{Ba}$ as the surface concentration of $\mathrm{Ba}$ decreased. Without the dependency on surface concentration, dissolved $\mathrm{Ba}$ will be incorporated into particulate $\mathrm{Ba}$ (relative to the $\mathrm{P}_{\mathrm{Org}}$ flux) regardless of the surface water concentration. Therefore, at high levels of $P_{\text {Org }}$, surface water will become depleted in $\mathrm{Ba}$ if there is no other increase in Ba influx. According to this model, the maximum increase of $\mathrm{P}_{\mathrm{Org}}$ that can be maintained for $1 \mathrm{kyr}$ without depleting the surface ocean of $\mathrm{Ba}$ is in the range of $36 \%$ increase. For any increase in $\mathrm{P}_{\mathrm{Org}}$ of more than $36 \%$, an increase in the flux of Ba to the surface water is necessary. It is important to emphasize that this experiment increases only $\mathrm{P}_{\mathrm{Org}}$. However, in the actual ocean, in order to increase $P_{\text {Org }}$ there must be an increase in nutrient input, which would also supply more Ba. Enhanced nutrients (and Ba input) could come from an increase in riverine/groundwater input or enhanced upwelling of deep water to surface water. Therefore, although the new parameterizations of Equations (4) and (5) cause an increased sensitivity in the surface reservoir that results in decreasing Ba concentrations, this does not discount their validity, as any increase in ocean productivity and export production will require also an increase in nutrient supply. Changes in nutrient influx and availability can be driven by a multitude of factors, such as wind-induced enhancement of upwelling regions, 
or increased riverine runoff. In either case both factors are also associated with an increase in Ba supply, as Ba distribution and inputs in the ocean are the same as those of nutrients [22,47].

Time periods of enhanced export production, with levels twice that of modern day, such as those seen during glacials and during the Miocene, are thought to be caused by increases in Ekman-induced upwelling or nutrient content in the upwelled water [105,122]. In the box model, that would increase the exchange rate between surface and deep water (the parameter C; Table 2). By enhancing the exchange rate by $65 \%$, more Ba-rich deep water is brought to the surface, supplying the surface water with a higher amount of dissolved Ba (Figure 6; red). With the increase in supply of Ba to the surface water, export production $\left(\mathrm{P}_{\mathrm{Org}}\right)$ can also be doubled in the model. The surface water can sustain a doubling of export production over $1 \mathrm{kyr}$ without depleting the Ba in the surface layer. However, if continued for more than $1 \mathrm{kyr}$ a depletion of Ba dissolved in surface waters will occur. Thus, a prolonged increase of primary and export production requires increasing an additional flux of nutrients and Ba to the surface, such as through rivers and groundwater input or increased upwelling.

Table 1. Flux equations to describe the marine Ba cycle from Dickens et al. [27] with changes made to the formulation of the particulate rain of Ba flux $\left(\mathrm{F}_{\mathrm{PR}}\right)$. Variables defined in Table 2.

\begin{tabular}{|c|c|}
\hline Description & Equation \\
\hline Changes in surface water Ba standing stock & $\frac{d a_{s h}}{d t}=F_{R i v}+F_{U p}-F_{D w}-F_{P R}$ \\
\hline Changes in deep water Ba standing stock & $\frac{d \mathrm{dBap}_{\mathrm{Dp}}}{\mathrm{dt}}=\mathrm{F}_{\mathrm{Reg}}+\mathrm{F}_{\mathrm{Hyd}}+\mathrm{F}_{\mathrm{Cold}}+\mathrm{F}_{\mathrm{Dw}}-\mathrm{F}_{\mathrm{Up}}$ \\
\hline Ba concentration in surface water & {$[\mathrm{Ba}]_{S h}=\frac{B a_{S h}}{M_{S h}}$} \\
\hline Ba concentration in deep water & {$[\mathrm{Ba}]_{\mathrm{Dp}}=\frac{\mathrm{Ba}_{\mathrm{Dp}}}{\mathrm{M}_{\mathrm{Dp}}}$} \\
\hline Downwelling flux & $\mathrm{F}_{\mathrm{Dw}}=[\mathrm{Ba}]_{\mathrm{Sh}} \mathrm{C}$ \\
\hline Upwelling flux & $\mathrm{F}_{\mathrm{Up}}=[\mathrm{Ba}]_{\mathrm{Dp}} \mathrm{C}$ \\
\hline Particulate rain (Dickens et al. [27]) & $\mathrm{F}_{\mathrm{PR}}=[\mathrm{Ba}]_{\mathrm{Sh}} \mathrm{D} \mathrm{P}_{\mathrm{Org}}$ \\
\hline Particulate rain (this study) & $\mathrm{F}_{\mathrm{PR}}=\mathrm{b} \times \mathrm{P}_{\mathrm{Org}} \mathrm{OR} \mathrm{F}_{\mathrm{PR}}=\mathrm{P}_{\mathrm{Org}}{ }^{\mathrm{e}}$ \\
\hline Dissolution flux & $\mathrm{F}_{\mathrm{Dis}}=\mathrm{F}_{\mathrm{PR}}\left(1-\mathrm{k} \frac{[\mathrm{Ba}]_{\mathrm{Dp}}}{[\mathrm{Ba}]_{\mathrm{Sat}}}\right)$ \\
\hline Burial flux & $\mathrm{F}_{\mathrm{Bur}}=\mathrm{F}_{\mathrm{PR}}-\mathrm{F}_{\mathrm{Dis}}$ \\
\hline
\end{tabular}

Table 2. List of parameters and constants used to describe the marine Ba cycle from Dickens et al. [27], with the addition of constants ' $b$ ' and ' $e^{\prime}$ used here in the new formulation of $F_{P R}$.

\begin{tabular}{|c|c|c|c|}
\hline Parameter & Description & Units & Standard Conditions \\
\hline $\mathrm{Ba}_{\mathrm{Dp}}$ & Standing stock of Ba in deep water & Gmol & 140,148 \\
\hline $\mathrm{F}_{\mathrm{Up}}$ & Upwelling Ba flux & $\mathrm{Gmol} / \mathrm{yr}$ & 128.15 \\
\hline$F_{D w}$ & Downwelling Ba flux & $\mathrm{Gmol} / \mathrm{yr}$ & 39.80 \\
\hline $\mathrm{F}_{\mathrm{PR}}$ & Particulate rain Ba flux & $\mathrm{Gmol} / \mathrm{yr}$ & 103.10 \\
\hline $\mathrm{F}_{\mathrm{Hyd}}$ & Hydrothermal Ba flux & $\mathrm{Gmol} / \mathrm{yr}$ & 3.35 \\
\hline $\mathrm{F}_{\text {Cold }}$ & Cold seep Ba flux & $\mathrm{Gmol} / \mathrm{yr}$ & 0.00 \\
\hline $\mathrm{F}_{\mathrm{Bur}}$ & Burial Ba flux & $\mathrm{Gmol} / \mathrm{yr}$ & 18.10 \\
\hline$[\mathrm{Ba}]_{\mathrm{Sh}}$ & Dissolved $\mathrm{Ba}$ in surface water & $\mathrm{nmol} / \mathrm{kg}_{\mathrm{sw}}$ & 36 \\
\hline$[\mathrm{Ba}]_{\mathrm{Dp}}$ & Dissolved Ba in deep water & $\mathrm{nmol} / \mathrm{kg}_{\mathrm{sw}}$ & 116 \\
\hline$[\mathrm{Ba}]_{\text {Sat }}$ & Dissolved $\mathrm{Ba}$ at saturation & $\mathrm{mol} / \mathrm{kg}_{\mathrm{sw}}$ & 330 \\
\hline $\mathrm{b}$ & (this study) Linear constant relating $\mathrm{F}_{\mathrm{PR}}$ to $\mathrm{P}_{\mathrm{Org}}$ & unitless & 0.0137 \\
\hline $\mathrm{e}$ & (this study) Exponential constant relating $\mathrm{F}_{\mathrm{PR}}$ to $\mathrm{P}_{\mathrm{Org}}$ & unitless & 0.8554 \\
\hline$P_{\text {org }}$ & Sinking organic carbon flux & $\mathrm{Gmol} / \mathrm{yr}$ & 7500 \\
\hline $\mathrm{f}$ & Fraction of $F_{P R}$ buried (0-1) & unitless & 0.17556 \\
\hline $\mathrm{k}$ & "Time factor" for barite preservation (0-1) & unitless & 0.4994 \\
\hline $\mathrm{M}_{\mathrm{Sh}}$ & Mass of surface water & $\mathrm{kg}$ & $1.04 \times 10^{20}$ \\
\hline $\mathrm{M}_{\mathrm{Dp}}$ & Mass of deep-water & $\mathrm{kg}$ & $1.21 \times 10^{21}$ \\
\hline
\end{tabular}


In the second set of sensitivity experiments we used a power function to describe the relationship between $F_{P R}$ and $P_{\text {Org, }}$, which was suggested by Francois et al. [40] to better represent the observation that very high areas of productivity have a lower barite flux to the seafloor than expected.

$$
\mathrm{F}_{\mathrm{PR}}=\mathrm{P}_{\mathrm{Org}}{ }^{\mathrm{e}}
$$

where e is a constant established for an exponential relationship. The value of e is set to 0.8554 to maintain mass balance. Generally, the results are very similar to those in the previous set of experiments (Figure 6). However, the exponential relationship yields a slightly lower barite accumulation during times of enhanced $\mathrm{C}$ export, and results in a slightly higher concentration of dissolved Ba in surface waters and a lower degree of removal.

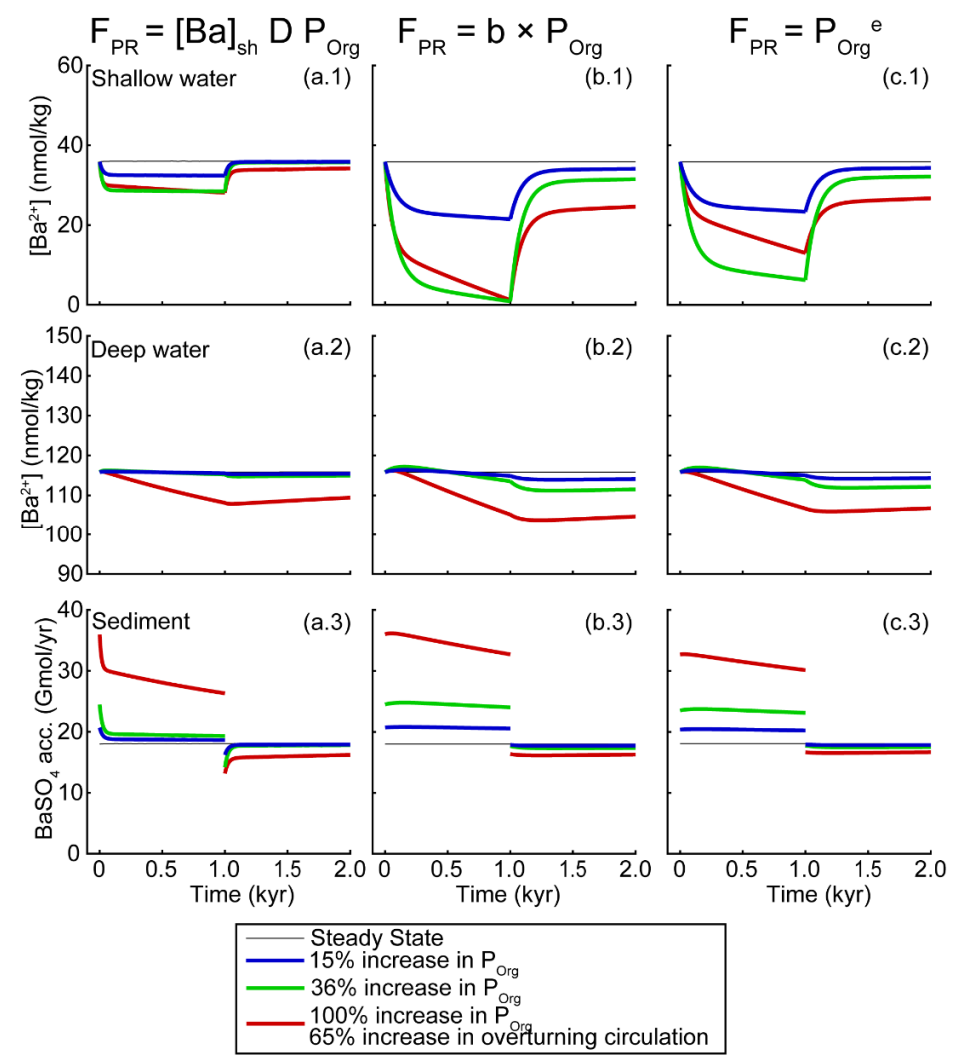

Figure 6. Box model results from Dickens et al. [27] compared with new results with two equations to describe $F_{P R}$. The three columns (a-c) show results using different relationships of $F_{P R}$. The three rows (1-3) show the dissolved concentration of $\mathrm{Ba}^{2+}$ in surface water (top; a.1, b.1, c.1), the dissolved concentration of $\mathrm{Ba}^{2+}$ in deep water (middle; a.2, b.2, c.2), and the accumulation of barite $\left(\mathrm{BaSO}_{4}\right)$ in the sediment (bottom; a.3, b.3, c.3). The left column shows results using the relationship for $\mathrm{F}_{\mathrm{PR}}$ described by Dickens et al. [27] (a.1, a.2, a.3). The middle column (shows results using a linear relationship b.1, b.2, b.3). The right column shows results using an exponential relationship (c.1, c.2, c.3). Different colors represent scenarios of perturbations (see legend), each running for $1 \mathrm{kyr}$, then a return to steady-state conditions.

Sensitivity to Changes in Ba Inputs

The magnitude of Ba input per year (flux) into surface and deep oceans is not well quantified. The model above uses terrestrial inputs that represent the maximum values within the range of modern estimates. The model also includes input of Ba to the deep ocean from hydrothermal sources, which may not actually be a significant source of Ba due to the local precipitation of barite near these sources. In this section, for comparison we use the minimum values within the range of modern estimates 
for Ba inputs into the ocean. Riverine input is now set to the minimum within the range of modern estimates, discussed in Section 2.1, which is $2 \mathrm{nmol} \mathrm{cm}^{-2} \mathrm{yr}^{-1}$, plus the input from groundwater sources $\left(0.46 \mathrm{nmol} \mathrm{cm}^{-2} \mathrm{yr}^{-1}\right)$. Thus, the terrestrial input is lowered to $2.46 \mathrm{nmol} \mathrm{cm}^{-2} \mathrm{yr}^{-1}$, or $5.904 \mathrm{Gmol}$ $\mathrm{yr}^{-1}$. The hydrothermal input is set to zero. In order to maintain mass balance in the model, the fluxes within the surface and deep ocean boxes must be changed. Keeping the inventory of Ba constant, as well as the rate of overturning circulation (variable $\mathrm{C}$ in Table 2), the variables that are used to relate $\mathrm{F}_{\mathrm{PR}}$ to $\mathrm{P}_{\mathrm{Org}}$ must be changed (from Equations (4) and (5)) to account for the lower $\mathrm{F}_{\mathrm{PR}}$ flux magnitude. The value of $b$ in Equation (4) is changed to 0.0126, the value of e in Equation (5) is changed to 0.8524. Additionally, to account for the decrease in the burial flux (which is equivalent to terrestrial input), it is also necessary to decrease the fraction of $F_{P R}$ that is buried (variable $f$ in Table 2), which is also used to calculate the dissolution flux of $\mathrm{Ba}, \mathrm{F}_{\mathrm{Dis}}$. The variable $\mathrm{f}$ is decreased to 0.0626 . By decreasing the input fluxes, the fraction of exported Ba that is dissolved within the water column is significantly decreased in order to maintain mass balance, from $17.5 \%$ to $6.26 \%$. Figure 7 shows the same three experiments as performed above but with the new set of parameters. There is not a significant change with regard to surface and deep-water Ba concentration in response to each of the perturbations. There is actually a smaller degree of depletion in surface waters with each perturbation due to the decreased export flux. Similarly, barite accumulation is enhanced (in response to the perturbations) and maintained for the entire duration.

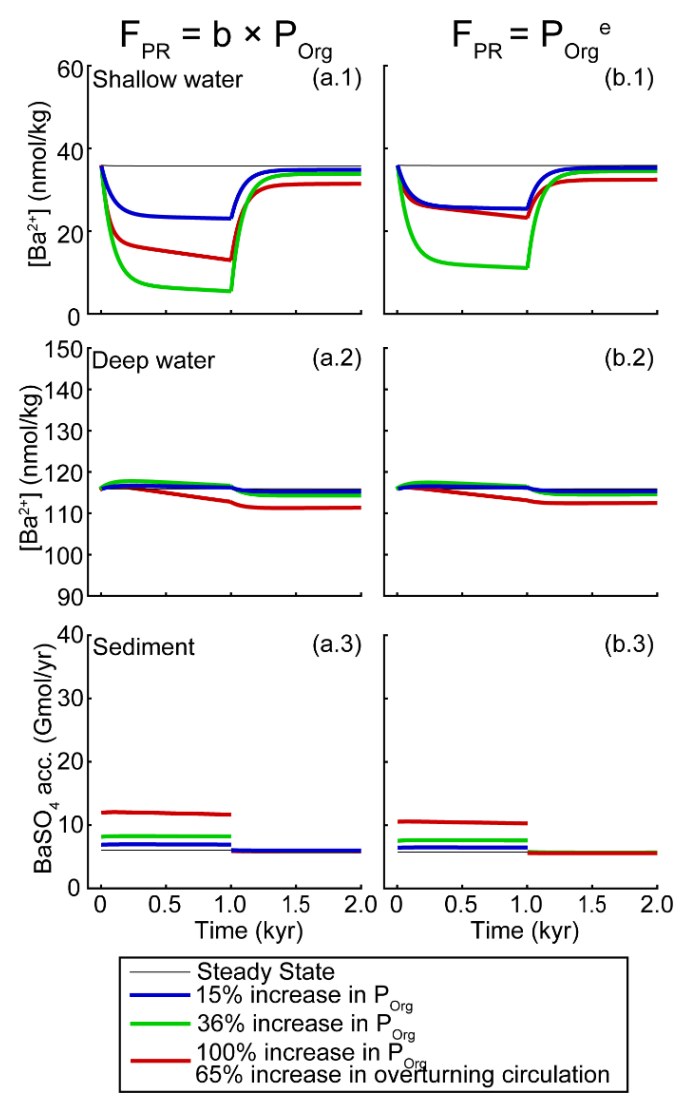

Figure 7. Box model results with decreased terrestrial input and zero hydrothermal input. Fluxes within the surface and deep water boxes are also changed to maintain mass balance in the model. The two columns $(\mathbf{a}, \mathbf{b})$ show results using different relationships of $F_{P R}$. The three rows $(\mathbf{1}, \mathbf{2}, \mathbf{3})$ show the dissolved concentration of $\mathrm{Ba}$ in surface water (top; a.1, b.1), the dissolved concentration of $\mathrm{Ba}$ in deep water (middle; a.2, b.2), and the accumulation of barite $\left(\mathrm{BaSO}_{4}\right)$ in the sediment (bottom; a.3, b.3). The left column shows results using a linear relationship for $\mathrm{F}_{\mathrm{PR}}(\mathbf{a . 1}$, a.2, a.3), the right column shows results using an exponential relationship (b.1, b.2, b.3). Different colors represent scenarios of perturbations (see legend), each running for $1 \mathrm{kyr}$, then a return to steady-state conditions. 


\subsection{Implications, Limitations, and Future Works}

The box model results for the new parameterizations of the relationship between export production and particulate Ba flux (Equations (4) and (5)) indicate that periods of enhanced BAR do not necessarily require an increase in the flux of new Ba into the ocean (i.e., require a new source of $\mathrm{Ba}$ ), as has been argued [27]. Changing the relationship to remove the dependency of Ba utilization on surface water dissolved Ba concentration, which is arguably more representative of the observed relationship in the modern day, results in a sustained increase of BAR that occurs over the entirety of the 1 kyr $P_{\text {Org }}$ flux increase, in contrast to a sharp rise and fall as seen in the previous model of Dickens et al. [27]. The new modeled relationships show that it is possible to maintain enhanced BAR during extended times of enhanced C export, however, over time these periods of enhanced BAR will lead to depletion of surface water $\mathrm{Ba}$ if not balanced by an increase in the source of Ba to the surface oceans. Yet, it is important to note that mechanisms that lead to enhanced primary and export production will also lead to enhanced delivery of dissolved Ba to surface waters, such as increased upwelling or riverine runoff. Increases in the remineralization efficiency of organic matter in deeper water will also increase Ba in the upwelled water and replenish the surface layer. Thus, it is likely that this balance is satisfied during time periods of observed increases in barite accumulation, such as over glacial periods or during the events seen in the PETM. Moreover, the increases in BAR during the PETM do not require an increase in deep water Ba saturation and enhanced preservation to be invoked, as also supported by $\mathrm{Sr} / \mathrm{Ba}$ ratios in barite over this time interval which do not reveal any change in the barite saturation state of the ocean [135].

Thus far, the marine Ba cycle has been modeled only using two-box models. These models have provided valuable insight into some of the processes involved, however, they do not allow for investigation of spatial distribution and do not include processes that may change remineralization efficiency (such as temperature) or possible ecosystem changes that could affect the uptake of Ba by organisms and the sinking particles and their $\mathrm{C}_{\mathrm{Org}} / \mathrm{Ba}$ ratio. More detailed insight into the processes that control the ocean Ba inventory, its spatial distribution and its sensitivity to perturbations is needed for a better understanding of the links between productivity, the Ba and $\mathrm{C}$ global biogeochemical cycles, and climate on geologic timescales. Future modeling efforts should focus on resolving the spatial distribution, such as with a coupled biogeochemical ocean general circulation model. Additionally, it is important to understand why the $\mathrm{Ba}_{\mathrm{ex}}$ flux to the seafloor is lower than expected in areas of very high $\mathrm{C}$ export fluxes in order to model this process more precisely [54]. We also know that Ba concentrations in some anoxic basins are very high and this was not taken into account in the model because these areas reflect a very small fraction of the overall ocean today, although such areas may have been more important in the geological past. In order to ensure correct interpretations of $\mathrm{Ba}$ as a paleoproxy for export production, we must also be able to resolve differences in ocean basins by increasing the complexity and resolution of the Ba cycle model. Increased complexity and resolution will allow for investigation into spatial variations as well as how sensitive Ba is to a variety of processes, such as changes in riverine input, changes in dissolution rates, or changes in seawater temperature.

\section{Concluding Remarks}

Substantial progress has been recently made in the effort to constrain the marine Ba cycle, particularly focused on understanding the mechanism for barite precipitation within sinking organic matter debris as well as the development of $\mathrm{Ba}$ isotopes as a tool to investigate Ba cycling. The accumulation of marine barite in ocean sediments has been used in a wide variety of studies to investigate variations in export production in both the present day and in the geologic past. However, there still is more to be investigated. Particularly, more work is needed to constrain rates and controls on barium fluxes associated with input, uptake, precipitation, and dissolution both in the water column and in sediments, as well as how these may fluctuate spatially and temporally in the ocean. These new constraints will be vitally important for refined parameterizations of the Ba cycle that can be incorporated into biogeochemical models. 
A new approach to modeling the marine Ba cycle as a two-box model using different parameterizations of the relationship between $C$ export and barite precipitation in the water column shows similar results between a linear and logarithmic parameterization, though a logarithmic relationship shows a lesser degree of depletion in surface waters with enhanced levels of $C$ export. Additionally, the new parameterizations show that periods of enhanced $C$ export can lead to sustained increases in barite accumulation, which is different from previous modeling results. Though the two-box model is useful in investigating overall processes, it does not allow for the investigation of spatial variability, which has been established as an important aspect of the marine Ba cycle and its relation to $C$ export.

Author Contributions: Conceptualization, S.C.C., E.M.G., and A.P.; methodology, S.C.C.; software, S.C.C.; formal analysis, S.C.C.; writing-original draft preparation, S.C.C.; writing-review and editing, S.C.C., A.P., and E.M.G.; visualization, S.C.C.; funding acquisition, S.C.C., E.M.G., and A.P. All authors have read and agreed to the published version of the manuscript.

Funding: S.C. Carter received support from the Presidential Fellowship at Ohio State University (OSU) during the completion of this project, as well as funding for travel from the National Science Foundation (NSF), The Oceanography Society, and Friends of Orton Hall at OSU to present this research at international meetings. This work was partially supported by NSF grant OCE-1536630 to E.M.G and OCE-0449732 to A.P.

Acknowledgments: S.C. Carter would like to thank the Graduate School at OSU for their support during the completion of this project, as well as the National Science Foundation, the Oceanography Society, and Friends of Orton Hall at OSU for their travel support to attend meetings to present this research. The authors would also like to thank Francisca Martínez-Ruiz for providing a SEM image of barite from the water column. Lastly, we thank three anonymous reviewers for their helpful comments, which greatly aided in the improvement of the present manuscript.

Conflicts of Interest: The authors declare no conflict of interest.

\section{References}

1. Berner, R.A.; Lasaga, A.C.; Garrels, R.M. The carbonate-silicate geochemical cycle and its effect on atmospheric carbon dioxide over the past 100 million years. Am. J. Sci. 1983, 283, 641-683. [CrossRef]

2. Sarmiento, J.L.; Toggweiler, J.R. A new model for the role of the oceans in determining atmospheric $p \mathrm{CO}_{2}$. Nature 1984, 308, 621-624. [CrossRef]

3. Falkowski, M.; Barber, B.J.; Smetacek, A.L.; Engelhardt, K.A.M.; Ruesink, J.L.; Srivastava, D.S. Biogeochemical controls and feedbacks on ocean primary production. Science 1998, 281, 200-207. [CrossRef] [PubMed]

4. Siegel, D.A.; Buesseler, K.O.; Doney, S.C.; Sailley, S.F.; Behrenfeld, M.J.; Boyd, P.W. Global assessment of ocean carbon export by combining satellite observations and food-web models. Glob. Biogeochem. Cycles 2014, 28, 181-196. [CrossRef]

5. Volk, T.; Hoffert, M.I. Ocean carbon pumps: Analysis of relative strengths and efficiencies in ocean-driven atmospheric $\mathrm{CO}_{2}$ changes. Geophys. Monogr. Ser. 1985, 32, 99-110.

6. Arndt, S.; Jørgensen, B.B.; LaRowe, D.E.; Middelburg, J.J.; Pancost, R.D.; Regnier, P. Quantifying the degradation of organic matter in marine sediments: A review and synthesis. Earth-Sci. Rev. 2013, 123, 53-86. [CrossRef]

7. Paytan, A. Ocean paleoproductivity. In Encyclopedia of Paleoclimatology and Ancient Environments; Gornitz, V., Ed.; Kluwer Academic Publishers: Berlin Germany, 2008; pp. 643-651. ISBN 978-1-4020-4551-6.

8. Wolgemuth, K.; Broecker, W.S. Barium in sea water. Earth Planet. Sci. Lett. 1970, 8, 372-378. [CrossRef]

9. Paytan, A.; Kastner, M. Benthic Ba fluxes in the central Equatorial Pacific, implications for the oceanic Ba cycle. Earth Planet. Sci. Lett. 1996, 142, 439-450. [CrossRef]

10. Collier, R.W.; Edmond, J.M. The trace elements geochemistry of marine biogenic particulate matter. Prog. Ocean. 1984, 13. [CrossRef]

11. Dymond, J.; Suess, E.; Lyle, M. Barium in deep-sea sediment: A geochemical proxy for paleoproductivity. Paleoceanography 1992, 7, 163-181. [CrossRef]

12. Bishop, J.K.B. The barite-opal-organic carbon association in oceanic particulate matter. Nature 1988, 332, 341-343. [CrossRef]

13. Faure, G. Principles and Applications of Geochemistry; Prentice-Hall: Upper Saddle River, NJ, USA, 1998. 
14. Bacon, M.P.; Edmond, J.M. Barium at Geosecs III in the southwest Pacific. Earth Planet. Sci. Lett. 1972, 16, 66-74. [CrossRef]

15. Church, T.M.; Wolgemuth, K. Marine barite saturation. Earth Planet. Sci. Lett. 1972, 15, 35-44. [CrossRef]

16. Li, Y.H.; Ku, T.L.; Mathieu, G.; Wolgemuth, K. Ba in the antarctic ocean and its implications regarding the marine geochemistry of Ba and ${ }^{226} \mathrm{Ra}^{*}$. Earth Planet. Sci. Lett. 1973, 19, 352-358. [CrossRef]

17. Chan, L.H.; Edmond, J.M.; Stallard, R.F.; Broecker, W.S.; Chung, Y.C.; Weiss, R.F.; Ku, T.L. Radium and barium at GEOSECS stations in the Atlantic and Pacific. Earth Planet. Sci. Lett. 1976, 32, 258-267. [CrossRef]

18. Chan, L.H.; Drummond, D.; Edmond, J.M.; Grant, B. On the barium data from the Atlantic GEOSECS expedition. Deep. Res. 1977, 24, 613-649. [CrossRef]

19. Bridgestock, L.; Hsieh, Y.-T.; Porcelli, D.; Homoky, W.B.; Bryan, A.; Henderson, G.M. Controls on the barium isotope compositions of marine sediments. Earth Planet. Sci. Lett. 2018, 481, 101-110. [CrossRef]

20. Hsieh, Y.T.; Henderson, G.M. Barium stable isotopes in the global ocean: Tracer of Ba inputs and utilization. Earth Planet. Sci. Lett. 2017, 473, 269-278. [CrossRef]

21. Bates, S.L.; Hendry, K.R.; Pryer, H.V.; Kinsley, C.W.; Pyle, K.M.; Woodward, E.M.S.; Horner, T.J. Barium isotopes reveal role of ocean circulation on barium cycling in the Atlantic. Geochim. Cosmochim. Acta 2017, 204, 286-299. [CrossRef]

22. Horner, T.J.; Kinsley, C.W.; Nielsen, S.G. Barium-isotopic fractionation in seawater mediated by barite cycling and oceanic circulation. Earth Planet. Sci. Lett. 2015, 430, 511-522. [CrossRef]

23. Hemsing, F.; Hsieh, Y.-T.; Bridgestock, L.; Spooner, P.T.; Robinson, L.F.; Frank, N.; Henderson, G.M. Barium isotopes in cold-water corals. Earth Planet. Sci. Lett. 2018, 491, 183-192. [CrossRef]

24. Elderfield, H.; Schultz, A. Mid-ocean ridge hydrothermal fluxes and the chemical composition of the ocean. Annu. Rev. Earth Planet. Sci. 1996, 24, 191-224. [CrossRef]

25. Monnin, C.; Wheat, C.G.; Dupre, B.; Elderfield, H.; Mottl, M.M. Barium geochemistry in sediment pore waters and formation waters of the oceanic crust on the eastern flank of the Juan de Fuca Ridge (ODP Leg 168). Geochem., Geophys. Geosystems 2001, 2. [CrossRef]

26. Torres, M.E.; Bohrmann, G.; Suess, E. Authigenic barites and fluxes of barium associated with fluid seeps in the Peru subduction zone. Earth Planet. Sci. Lett. 1996, 144, 469-481. [CrossRef]

27. Dickens, G.R.; Fewless, T.; Thomas, E.; Bralower, T.J. Excess barite accumulation during the Paleocene-Eocene Thermal Maximum: Massive input of dissolved barium from seafloor gas hydrate reservoirs. In Causes and Consequences of Globally Warm Climates in the Early Paleogene; Geological Society of America: Boulder, CO, USA, 2003; Volume 369, pp. 11-23.

28. Dehairs, F.; Chesselet, R.; Jedwab, J. Discrete suspended particles of barite and the barium cycle in the open ocean. Earth Planet. Sci. Lett. 1980, 49, 528-550. [CrossRef]

29. Ganeshram, R.S.; François, R.; Commeau, J.; Brown-Leger, S.L. An experimental investigation of barite formation in seawater. Geochim. Cosmochim. Acta 2003, 67, 2599-2605. [CrossRef]

30. Van Beek, P.; François, R.; Conte, M.; Reyss, J.L.; Souhaut, M.; Charette, M. ${ }^{228}{ }_{\mathrm{Ra}}{ }^{226} \mathrm{Ra}$ and ${ }^{226} \mathrm{Ra} / \mathrm{Ba}$ ratios to track barite formation and transport in the water column. Geochim. Cosmochim. Acta 2007, 71, 71-86. [CrossRef]

31. Martinez-Ruiz, F.; Jroundi, F.; Paytan, A.; Guerra-Tschuschke, I.; Abad, M.D.M.; González-Muñoz, M.T. Barium bioaccumulation by bacterial biofilms and implications for Ba cycling and use of Ba proxies. Nat. Commun. 2018, 9, 1-9. [CrossRef] [PubMed]

32. Martinez-Ruiz, F.; Paytan, A.; Gonzalez-Muñoz, M.T.; Jroundi, F.; Abad, M.M.; Lam, P.J.; Bishop, J.K.B.; Horner, T.J.; Morton, P.L.; Kastner, M. Barite formation in the ocean: Origin of amorphous and crystalline precipitates. Chem. Geol. 2019, 511, 441-451. [CrossRef]

33. Bertram, M.A.; Cowen, J.P. Morphological and compositional evidence for biotic precipitation of marine barite. J. Mar. Res. 1997, 55, 577-593. [CrossRef]

34. Dehairs, F.; Jacquet, S.; Savoye, N.; Van Mooy, B.A.S.; Buesseler, K.O.; Bishop, J.K.B.; Lamborg, C.H.; Elskens, M.; Baeyens, W.; Boyd, P.W.; et al. Barium in twilight zone suspended matter as a potential proxy for particulate organic carbon remineralization: Results for the North Pacific. Deep. Res. Part II Top. Stud. Oceanogr. 2008, 55, 1673-1683. [CrossRef]

35. Fisher, N.S.; Guillard, R.R.L.; Bankston, D.C. The accumulation of barium by marine phytoplankton grown in culture. J. Mar. Res. 1991, 49, 339-354. [CrossRef] 
36. Goldberg, E.D.; Arrhenius, G.O.S. Chemistry of Pacific pelagic sediments. Geochim. Cosmochim. Acta 1958, 13, 153-212. [CrossRef]

37. Bernstein, R.E.; Byrne, R.H.; Betzer, P.R.; Greco, A.M. Morphologies and transformations of celestite in seawater: The role of acantharians in strontium and barium geochemistry. Geochim. Cosmochim. Acta 1992, 56, 3273-3279. [CrossRef]

38. Bernstein, R.E.; Byrne, R.H.; Schijf, J. Acantharians: A missing link in the oceanic biogeochemistry of barium. Deep. Res. Part I Oceanogr. Res. Pap. 1998, 45, 491-505. [CrossRef]

39. Chow, T.J.; Goldberg, E.D. On the marine geochemistry of barium. Geochim. Cosmochim. Acta 1960, 20, 192-198. [CrossRef]

40. Francois, R.; Honjo, S.; Manganini, S.J.; Ravizza, G.E. Biogenic barium fluxes to the deep sea: Implications for paleoproductivity reconstruction. Glob. Biogeochem. Cycles 1995, 9, 289-303. [CrossRef]

41. McManus, J.; Berelson, W.M.; Klinkhammer, G.P.; Johnson, K.S.; Coale, K.H.; Anderson, R.F.; Kumar, N.; Burdige, D.J.; Hammond, D.E.; Brumsack, H.J.; et al. Geochemistry of barium in marine sediments: Implications for its use as a paleoproxy. Geochim. Cosmochim. Acta 1998, 62, 3453-3473. [CrossRef]

42. Klump, J.; Hebbeln, D.; Wefer, G. High concentrations of biogenic barium in Pacific sediments after termination I-A signal of changes in productivity and deep water chemistry. Mar. Geol. 2001, 177, 1-11. [CrossRef]

43. McManus, J.; Berelson, W.M.; Hammond, D.E.; Klinkhammer, G.P. Barium cycling in the North Pacific: Implications for the utility of Ba as a paleoproductivity and paleoalkalinity proxy. Paleoceanography 1999, 14, 53-61. [CrossRef]

44. Paytan, A.; Kastner, M.; Chavez, F.P. Glacial to interglacial fluctuations in productivity in the equatorial Pacific as indicated by marine barite. Science 1996, 274, 1355-1357. [CrossRef] [PubMed]

45. Monnin, C.; Jeandel, C.; Cattaldo, T.; Dehairs, F. The marine barite saturation state of the world's oceans. Mar. Chem. 1999, 65, 253-261. [CrossRef]

46. Hanor, J.S.; Chan, L.-H. Non-conservative behavior of barium during mixing of Mississippi River and Gulf of Mexico waters. Earth Planet. Sci. Lett. 1977, 37, 242-250. [CrossRef]

47. Cao, Z.; Siebert, C.; Hathorne, E.C.; Dai, M.; Frank, M. Corrigendum to "Constraining the oceanic barium cycle with stable barium isotopes" [Earth Planet. Sci. Lett. 434 (2016) 1-9]. Earth Planet. Sci. Lett. 2020, 530, 116003. [CrossRef]

48. Coffey, M.; Dehairs, F.; Collette, O.; Luther, G.; Church, T.; Jickells, T. The behavior of dissolved barium in estuaries. Estuar. Coast. Shelf Sci. 1997, 45, 113-121. [CrossRef]

49. Joung, D.; Shiller, A.M. Dissolved barium behavior in Louisiana Shelf waters affected by the Mississippi/Atchafalaya River mixing zone. Geochim. Cosmochim. Acta 2014, 141, 303-313. [CrossRef]

50. Santos, I.R.; Burnett, W.C.; Misra, S.; Suryaputra, I.G.N.A.; Chanton, J.P.; Dittmar, T.; Peterson, R.N.; Swarzenski, P.W. Uranium and barium cycling in a salt wedge subterranean estuary: The influence of tidal pumping. Chem. Geol. 2011, 287, 114-123. [CrossRef]

51. Schlitzer, R.; Anderson, R.F.; Dodas, E.M.; Lohan, M.; Geibert, W.; Tagliabue, A.; Bowie, A.; Jeandel, C.; Maldonado, M.T.; Landing, W.M.; et al. The GEOTRACES Intermediate Data Product 2017. Chem. Geol. 2018, 493, 210-223. [CrossRef]

52. Schlitzer, R. eGEOTRACES-Electronic Atlas of GEOTRACES Sections and Animated 3D Scenes. Available online: http://www.egeotraces.org (accessed on 9 May 2020).

53. Broecker, W.S.; Peng, T.-H. Tracers in the Sea; Lamont-Doherty Geologic Observatory: Palisades, NY, USA, 1982.

54. Dymond, J.; Collier, R. Particulate barium fluxes and their relationships to biological productivity. Deep. Res. Part II Top. Stud. Oceanogr. 1996, 43, 1283-1308. [CrossRef]

55. Von Damm, K.; Edmond, J.; Grant, B.; Measures, C.; Walden, B.; Weiss, R. Chemistry of submarine hydrothermal solutions at $21^{\circ} \mathrm{N}$, East Pacific Rise. Geochim. Cosmochim. Acta 1985, 49, 2197-2220. [CrossRef]

56. Edmond, J.M.; Boyle, E.D.; Drummond, D.; Grant, G. Desorption of Ba in the plume of the Zaire River. Neth. J. Sea Res. 1978, 12, 324-328. [CrossRef]

57. Das, A.; Krishnaswami, S. Barium in Deccan Basalt Rivers: Its Abundance, Relative Mobility and Flux. Aquat. Geochemistry 2006, 12, 221-238. [CrossRef] 
58. Mayfield, K.K.; Eisenhauer, A.; Santiago Ramos, D.P.; Higgins, J.A.; Horner, T.J.; Auro, M.; Magna, T.; Moosdorf, N.; Charette, M.A.; Gonneea, M.E.; et al. The importance of groundwater discharge in marine isotope budgets. Nat. Commun.. accepted.

59. Edmond, J.M.; Spivack, A.; Grant, B.C.; Ming-Hui, H.; Zexiam, C.; Sung, C.; Xiushau, Z. Chemical dynamics of the Changjiang estuary. Cont. Shelf Res. 1985, 4, 17-36. [CrossRef]

60. Roy-Barman, M.; Pons-Branchu, E.; Levier, M.; Bordier, L.; Foliot, L.; Gdaniec, S.; Ayrault, S.; Garcia-Orellana, J.; Masque, P.; Castrillejo, M. Barium during the GEOTRACES GA-04S MedSeA cruise: The Mediterranean Sea Ba budget revisited. Chem. Geol. 2019, 511, 431-440. [CrossRef]

61. Edmond, J.M.; Measures, C.; McDuff, R.E.; Chan, L.H.; Collier, R.; Grant, B.; Gordon, L.I.; Corliss, J.B. Ridge crest hydrothermal activity and the balances of the major and minor elements in the ocean: The Galapagos data. Earth Planet. Sci. Lett. 1979, 46, 1-18. [CrossRef]

62. Shaw, T.J.; Moore, W.S.; Kloepfer, J.; Sochaski, M.A. The flux of barium to the coastal waters of the southeastern USA: The importance of submarine groundwater discharge. Geochim. Cosmochim. Acta 1998, 62, 3047-3054. [CrossRef]

63. Hanor, J.S. Barite-Celestine Geochemistry and Environments of Formation. Rev. Mineral. Geochem. 2000, 40, 193-275. [CrossRef]

64. Stecher, H.A.; Kogut, M.B. Rapid barium removal in the Delaware estuary. Geochim. Cosmochim. Acta 1999, 63, 1003-1012. [CrossRef]

65. Moore, W.S. High fluxes of radium and barium from the mouth of the Ganges-Brahmaputra River during low river discharge suggest a large groundwater source. Earth Planet. Sci. Lett. 1997, 150, 141-150. [CrossRef]

66. Gonneea, M.E.; Mulligan, A.E.; Charette, M.A. Seasonal cycles in radium and barium within a subterranean estuary: Implications for groundwater derived chemical fluxes to surface waters. Geochim. Cosmochim. Acta 2013, 119, 164-177. [CrossRef]

67. Santos, R.V.; Sondag, F.; Cochonneau, G.; Lagane, C.; Brunet, P.; Hattingh, K.; Chaves, J.G.S. Source area and seasonal ${ }^{87} \mathrm{Sr} /{ }^{86} \mathrm{Sr}$ variations in rivers of the Amazon basin. Hydrol. Process. 2015, 29, 187-197. [CrossRef]

68. Lin, I.-T.; Wang, C.-H.; You, C.-F.; Lin, S.; Huang, K.-F.; Chen, Y.-G. Deep submarine groundwater discharge indicated by tracers of oxygen, strontium isotopes and barium content in the Pingtung coastal zone, southern Taiwan. Mar. Chem. 2010, 122, 51-58. [CrossRef]

69. Torres, M.E.; McManus, J.; Huh, C.-A. Fluid seepage along the San Clemente Fault scarp: Basin-wide impact on barium cycling. Earth Planet. Sci. Lett. 2002, 203, 181-194. [CrossRef]

70. McQuay, E.L.; Torres, M.E.; Collier, R.W.; Huh, C.-A.; McManus, J. Contribution of cold seep barite to the barium geochemical budget of a marginal basin. Deep Sea Res. Part I Oceanogr. Res. Pap. 2008, 55, 801-811. [CrossRef]

71. Torres, M.E.; Bohrmann, G.; Dubé, T.E.; Poole, F.G. Formation of modern and Paleozoic stratiform barite at cold methane seeps on continental margins. Geology 2003, 31, 897-900. [CrossRef]

72. Aloisi, G.; Wallmann, K.; Bollwerk, S.M.; Derkachev, A.; Bohrmann, G.; Suess, E. The effect of dissolved barium on biogeochemical processes at cold seeps. Geochim. Cosmochim. Acta 2004, 68, 1735-1748. [CrossRef]

73. Sternberg, E.; Tang, D.; Ho, T.Y.; Jeandel, C.; Morel, F.M.M. Barium uptake and adsorption in diatoms. Geochim. Cosmochim. Acta 2005, 69, 2745-2752. [CrossRef]

74. Stroobants, N.; Dehairs, F.; Goeyens, L.; Vanderheijden, N.; Van Grieken, R. Barite formation in the Southern Ocean water column. Mar. Chem. 1991, 35, 411-421. [CrossRef]

75. Dehairs, F.; Stroobants, N.; Goeyens, L. Suspended barite as a tracer of biological activity in the Southern Ocean. Mar. Chem. 1991, 35, 399-410. [CrossRef]

76. Dehairs, F.; Baeyens, W.; Goeyens, L. Accumulation of suspended barite at mesopelagic depths and export production in the Southern Ocean. Science 1992, 258, 1332-1335. [CrossRef] [PubMed]

77. Jacquet, S.H.M.; Dehairs, F.; Dumont, I.; Becquevort, S.; Cavagna, A.J.; Cardinal, D. Twilight zone organic carbon remineralization in the Polar Front Zone and Subantarctic Zone south of Tasmania. Deep. Res. Part II Top. Stud. Oceanogr. 2011, 58, 2222-2234. [CrossRef]

78. Planchon, F.; Cavagna, A.J.; Cardinal, D.; André, L.; Dehairs, F. Late summer particulate organic carbon export and twilight zone remineralisation in the Atlantic sector of the Southern Ocean. Biogeosciences 2013, 10, 803-820. [CrossRef]

79. Gonzalez-Muñoz, M.T.; Martinez-Ruiz, F.; Morcillo, F.; Martin-Ramos, J.D.; Paytan, A. Precipitation of barite by marine bacteria: A possible mechanism for marine barite formation. Geology 2012, 40, 675-678. [CrossRef] 
80. Torres-Crespo, N.; Martínez-Ruiz, F.; González-Muñoz, M.T.; Bedmar, E.J.; De Lange, G.J.; Jroundi, F. Role of bacteria in marine barite precipitation: A case study using Mediterranean seawater. Sci. Total Environ. 2015, 512-513, 562-571. [CrossRef] [PubMed]

81. Gonzalez-Muñoz, M.T.; Fernandez-Luque, B.; Martinez-Ruiz, F.; Chekroun, K.B.; Arias, J.M.; Rodriguez-Gallego, M.; Martinez-Canamero, M.; de Linares, C.; Paytan, A. Precipitation of barite by Myxococcus xanthus: Possible implications for the biogeocehmical cycle of barium. Appl. Environ. Microbiol. 2003, 69, 5722-5725. [CrossRef]

82. Bernstein, R.E.; Byrne, R.H. Acantharians and marine barite. Mar. Chem. 2004, 86, 45-50. [CrossRef]

83. Arrhenius, G.; Bonatti, E. Neptunism and vulcanism in the ocean. Prog. Oceanogr. 1965, 3, 7-22. [CrossRef]

84. Tendal, O.S. A monograph of the Xenophyophoria (Rhizopodea, Protozoa). Galathea Rep. 1972, 12, 7-103.

85. Gooday, A.J.; Nott, J.A. Intracellular Barite Crystals in Two Xenophyophores, Aschemonella Ramuliformis and Galatheammina Sp. (Protozoa: Rhizopoda) With Comments on the Taxonomy of A. Ramuliformis. J. Mar. Biol. Assoc. UK 1982, 62, 595-605. [CrossRef]

86. Swinbanks, D.D.; Shirayama, Y. High levels of natural radionuclides in a deep-sea infaunal xenophyophore. Nature 1986, 320, 354-358. [CrossRef]

87. Paytan, A.; Griffith, E.M. Marine barite: Recorder of variations in ocean export productivity. Deep. Res. Part II Top. Stud. Oceanogr. 2007, 54, 687-705. [CrossRef]

88. Falkner, K.K.; Klinkhammer, G.P.; Bowers, T.S.; Todd, J.F.; Lewis, B.L.; Landing, W.M.; Edmond, J.M. The behavior of barium in anoxic marine waters. Geochim. Cosmochim. Acta 1993, 57, 537-554. [CrossRef]

89. Blount, C.W. Barite solubilities and thermodynamic quantities up to $300 \mathrm{C}$ and 1400 bars. Am. Mineral. 1977, 62, 942-957.

90. Brumsack, H.J.; Gieskes, J.M. Interstitial water trace-metal chemistry of laminated sediments from the Gulf of California, Mexico. Mar. Chem. 1983, 14, 89-106. [CrossRef]

91. Von Breymann, M.T.; Emeis, K.C.; Camerlenghi, A. Geochemistry of sediments from the Peru upwelling area: Results from Sites 680, 682, 685 and 688. Geology 1990, 491-503. [CrossRef]

92. Von Breymann, M.T.; Brumsack, H.; Emeis, K.C. Depositional and Diagenetic Behavior of Barium in the Japan Sea. In Proceedings of the Ocean Drilling Program, 127/128 Scientific Results; Ocean Drilling Program: College Station, TX, USA, 1992; Volume 127, pp. 651-665.

93. Gingele, F.; Dahmke, A. Discrete barite particles and barium as tracers of paleoproductivity in south Atlantic sediments. Paleoceanography 1994, 9, 151-168. [CrossRef]

94. Torres, M.E.; Brumsack, H.J.; Bohrmann, G.; Emeis, K.C. Barite fronts in continental margin sediments: A new look at barium remobilization in the zone of sulfate reduction and formation of heavy barites in diagenetic fronts. Chem. Geol. 1996, 127, 125-139. [CrossRef]

95. Dickens, G.R. Sulfate profiles and barium fronts in sediment on the Blake Ridge: Present and past methane fluxes through a large as hydrate reservoir. Geochim. Cosmochim. Acta 2001, 65, 529-543. [CrossRef]

96. Griffith, E.M.; Paytan, A. Barite in the ocean-occurrence, geochemistry and palaeoceanographic applications. Sedimentology 2012, 59, 1817-1835. [CrossRef]

97. Paytan, A.; Mearon, S.; Cobb, K.; Kastner, M. Origin of marine barite deposits: Sr and S isotope characterization. Geology 2002, 30, 747-750. [CrossRef]

98. Griffith, E.M.; Paytan, A.; Wortmann, U.G.; Eisenhauer, A.; Scher, H.D. Combining metal and nonmetal isotopic measurements in barite to identify mode of formation. Chem. Geol. 2018, 500, 148-158. [CrossRef]

99. Von Allmen, K.; Böttcher, M.E.; Samankassou, E.; Nägler, T.F. Barium isotope fractionation in the global barium cycle: First evidence from barium minerals and precipitation experiments. Chem. Geol. 2010, 277, 70-77. [CrossRef]

100. Eagle, M.; Paytan, A.; Arrigo, K.R.; van Dijken, G.; Murray, R.W. A comparison between excess barium and barite as indicators of carbon export. Paleoceanography 2003, 18. [CrossRef]

101. Bains, S.; Norris, R.D.; Corfield, R.M.; Faul, K.L. Termination of global warmth at the Palaeocene/Eocene boundary through productivity feedback. Nature 2000, 407, 171-174. [CrossRef] [PubMed]

102. Schmitz, B. Barium, equatorial high productivity, and the northward wandering of the Indian continent. Paleoceanography 1987, 2, 63-77. [CrossRef]

103. Torfstein, A.; Winckler, G.; Tripati, A. Productivity feedback did not terminate the Paleocene-Eocene Thermal Maximum (PETM). Clim. Past 2010, 6, 265-272. [CrossRef] 
104. Nurnberg, C.C.; Bohrmann, G.; Schluter, M.; Frank, M. Barium accumulation in the Atlantic sector of the Southern Ocean: Results from 190,000 year records. Paleoceanography 1997, 12, 594-603. [CrossRef]

105. Ma, Z.; Ravelo, A.C.; Liu, Z.; Zhou, L.; Paytan, A. Export production fluctuations in the eastern equatorial Pacific during the Pliocene-Pleistocene: Reconstruction using barite accumulation rates. Paleoceanography 2015, 30, 1455-1469. [CrossRef]

106. Ma, Z.; Gray, E.; Thomas, E.; Murphy, B.; Zachos, J.; Paytan, A. Carbon sequestration during the Palaeocene-Eocene Thermal Maximum by an efficient biological pump. Nat. Geosci. 2014, 7, 382-388. [CrossRef]

107. Carter, S.C.; Griffith, E.M.; Penman, D.E. Peak intervals of equatorial Pacific export production during the middle Miocene climate transition. Geology 2016, 44, 923-926. [CrossRef]

108. Erhardt, A.M.; Pälike, H.; Paytan, A. High-resolution record of export production in the eastern equatorial Pacific across the Eocene-Oligocene transition and relationships to global climatic records. Paleoceanography 2013, 28, 130-142. [CrossRef]

109. Griffith, E.M.; Calhoun, M.; Thomas, E.; Averyt, K.; Erhardt, A.; Bralower, T.; Lyle, M.; Olivarez-Lyle, A.; Paytan, A. Export productivity and carbonate accumulation in the Pacific Basin at the transition from a greenhouse to icehouse climate (late Eocene to early Oligocene). Paleoceanography 2010, 25, 1-15. [CrossRef]

110. Moore, J.C.; Wade, B.S.; Westerhold, T.; Erhardt, A.M.; Coxall, H.K.; Baldauf, J.; Wagner, M. Equatorial Pacific productivity changes near the Eocene-Oligocene boundary. Paleoceanography 2014, 29, 825-844. [CrossRef]

111. Fagel, N.; Dehairs, F.; Peinert, R.; Antia, A.; André, L. Reconstructing export production at the NE Atlantic margin: Potential and limits of the Ba proxy. Mar. Geol. 2004, 204, 11-25. [CrossRef]

112. McManus, J.; Dymond, J.; Dunbar, R.B.; Collier, R.W. Particulate barium fluxes in the Ross Sea. Mar. Geol. 2002, 184, 1-15. [CrossRef]

113. Sun, W.P.; Han, Z.B.; Hu, C.Y.; Pan, J.M. Particulate barium flux and its relationship with export production on the continental shelf of Prydz Bay, east Antarctica. Mar. Chem. 2013, 157, 86-92. [CrossRef]

114. Sanchez-Vidal, A.; Collier, R.W.; Calafat, A.; Fabres, J.; Canals, M. Particulate barium fluxes on the continental margin: A study from the Alboran Sea (Western Mediterranean). Mar. Chem. 2005, 93, 105-117. [CrossRef]

115. Sternberg, E.; Jeandel, C.; Miquel, J.-C.; Gasser, B.; Souhaut, M.; Arraes-Mescoff, R.; Francois, R. Particulate barium fluxes and export production in the northwestern Mediterranean. Mar. Chem. 2007, 105, 281-295. [CrossRef]

116. Dehairs, F.; Fagel, N.; Antia, A.N.; Peinert, R.; Elskens, M.; Goeyens, L. Export production in the Bay of Biscay as estimated from barium-barite in settling material: A comparison with new production. Deep. Res. Part I Oceanogr. Res. Pap. 2000, 47, 583-601. [CrossRef]

117. Martin, J.H.; Knauer, G.A.; Karl, D.M.; Broenkow, W.W. VERTEX: Carbon cycling in the northeast Pacific. Deep. Res. 1987, 34, 267-285. [CrossRef]

118. Francois, R.; Honjo, S.; Krishfield, R.; Manganini, S. Factors controlling the flux of organic carbon to the bathypelagic zone of the ocean. Glob. Biogeochem. Cycles 2002, 16, 34-1-34-20. [CrossRef]

119. Klaas, C.; Archer, D.E. Association of sinking organic matter with various types of mineral ballast in the deep sea: Implications for the rain ratio. Glob. Biogeochem. Cycles 2002, 16, 63-1-63-14. [CrossRef]

120. Jeandel, C.; Tachikawa, K.; Bory, A.; Dehairs, F. Biogenic barium in suspended and trapped material as a tracer of export production in the tropical NE Atlantic (EUMELI sites). Mar. Chem. 2000, 71, 125-142. [CrossRef]

121. Berger, W.H. Cenozoic sedimentation in the eastern tropical pacific. Bull. Geol. Soc. Am. 1973, 84, 1941-1954. [CrossRef]

122. Moore, T.C.; Backman, J.; Raffi, I.; Nigrini, C.; Sanfilippo, A.; Pälike, H.; Lyle, M. Paleogene tropical Pacific: Clues to circulation, productivity, and plate motion. Paleoceanography 2004, 19. [CrossRef]

123. Chavez, F.P.; Barber, R.T. An estimate of new production in the equatorial Pacific. Deep. Res. 1987, 34, 1229-1242. [CrossRef]

124. Schenau, S.J.; Prins, M.A.; De Lange, G.J.; Monnin, C. Barium accumulation in the Arabian Sea: Controls on barite preservation in marine sediments. Geochim. Cosmochim. Acta 2001, 65, 1545-1556. [CrossRef]

125. Lyle, M.; Baldauf, J. Biogenic sediment regimes in the Neogene equatorial Pacific, IODP Site U1338: Burial, production, and diatom community. Palaeogeogr. Palaeoclimatol. Palaeoecol. 2015, 433, 106-128. [CrossRef]

126. Röhl, U.; Bralower, T.J.; Norris, R.D.; Wefer, G. New chronology for the late Paleocene thermal maximum and its environmental implications. Geology 2000, 28, 927. [CrossRef] 
127. Dickens, G.R.; O'Neil, J.R.; Rea, D.K.; Owen, R.M. Dissociation of oceanic methane hydrate as a cause of the carbon isotope excursion at the end of the Paleocene. Paleoceanography 1995, 10, 965-971. [CrossRef]

128. Zachos, J.; Pagani, M.; Sloan, L.; Thomas, E.; Billups, K. Trends, rhythms, and aberrations in global climate $65 \mathrm{Ma}$ to present. Science 2001, 292, 686-693. [CrossRef] [PubMed]

129. Bridgestock, L.; Hsieh, Y.-T.; Porcelli, D.; Henderson, G.M. Increased export production during recovery from the Paleocene-Eocene thermal maximum constrained by sedimentary Ba isotopes. Earth Planet. Sci. Lett. 2019, 510, 53-63. [CrossRef]

130. Bralower, T.J. Evidence of surface water oligotrophy during the Paleocene-Eocene thermal maximum: Nannofossil assemblage data from Ocean Drilling Program Site 690, Maud Rise, Weddell Sea. Paleoceanography 2002, 17, 13-1-13-12. [CrossRef]

131. Kelly, D.C.; Zachos, J.C.; Bralower, T.J.; Schellenberg, S.A. Enhanced terrestrial weathering/runoff and surface ocean carbonate production during the recovery stages of the Paleocene-Eocene thermal maximum. Paleoceanography 2005, 20. [CrossRef]

132. Gibbs, S.J.; Sheward, R.M.; Bown, P.R.; Poulton, A.J.; Alvarez, S.A. Warm plankton soup and red herrings: Calcareous nannoplankton cellular communities and the Palaeocene-Eocene Thermal Maximum. Philos. Trans. R. Soc. A Math. Phys. Eng. Sci. 2018, 376. [CrossRef]

133. Gibbs, S.J.; Stoll, H.M.; Bown, P.R.; Bralower, T.J. Ocean acidification and surface water carbonate production across the Paleocene-Eocene thermal maximum. Earth Planet. Sci. Lett. 2010, 295, 583-592. [CrossRef]

134. Naehr, T.H.; Stakes, D.S.; Moore, W.S. Mass wasting, ephemeral fluid flow, and barite deposition on the California continental margin. Geology 2000, 28, 315. [CrossRef]

135. Paytan, A.; Averyt, K.; Faul, K.; Gray, E.; Thomas, E. Barite accumulation, ocean productivity, and Sr/Ba in barite across the Paleocene-Eocene Thermal Maximum. Geology 2007, 35, 1139. [CrossRef]

(C) 2020 by the authors. Licensee MDPI, Basel, Switzerland. This article is an open access article distributed under the terms and conditions of the Creative Commons Attribution (CC BY) license (http://creativecommons.org/licenses/by/4.0/). 